\title{
Storage, mixing and fluxes of water in the critical zone across northern environments inferred by stable isotopes of soil water
}

\begin{tabular}{|r|l|}
\hline Journal: & Hydrological Processes \\
\hline Manuscript ID & HYP-17-0727.R2 \\
\hline Wiley - Manuscript type: & Special issue: Water in the Critical Zone \\
\hline Complete List of Authors: & $\begin{array}{l}\text { Sprenger, Matthias; University of Freiburg, School of Geoscience } \\
\text { Tetzlaff, Doerthe; University of Aberdeen, Northern Rivers Institute, School } \\
\text { of Geosciences } \\
\text { Buttle, James; Trent University, Geography } \\
\text { Carey, Sean; McMaster University, Geography \& Earth Sciences } \\
\text { McNamara, James; Boise State University, Geosciences } \\
\text { Laudon, Hjalmar; Swedish University of Agricultural Sciences, Forest } \\
\text { Ecology \& Management } \\
\text { Shatilla, Nadine; McMaster University, Geography \& Earth Sciences } \\
\text { Soulsby, Chris; University of Aberdeen, School of Geosciences }\end{array}$ \\
\hline Keywords: & $\begin{array}{l}\text { Isotopes, Soil Hydrology, Fractionation, Northern Environments, } \\
\text { Evaporation, Critical Zone }\end{array}$ \\
\hline &
\end{tabular}




\section{Storage, mixing and fluxes of water in the critical zone across 2 northern environments inferred by stable isotopes of soil water}

3 Matthias Sprenger ${ }^{1 *}$, Doerthe Tetzlaff ${ }^{2,3,1}$, Jim Buttle ${ }^{4}$, Sean K. Carey ${ }^{5}$, James P. McNamara ${ }^{6}$,

4 Hjalmar Laudon ${ }^{7}$, Nadine J. Shatilla ${ }^{5}$, Chris Soulsby ${ }^{1}$

$5 \quad{ }^{1}$ Northern Rivers Institute, School of Geosciences, University of Aberdeen, Aberdeen, UK

6 (matthias.sprenger@abdn.ac.uk, c.soulsby@abdn.ac.uk)

$7 \quad{ }^{2}$ IGB Leibniz Institute of Freshwater Ecology and Inland Fisheries

8 (d.tetzlaff@igb-berlin.de)

$9 \quad{ }^{3}$ Humboldt University Berlin

$10 \quad{ }^{4}$ School of the Environment, Trent University, Ontario, Canada. (jbuttle@trentu.ca)

$11{ }^{5}$ School of Geography and Earth Sciences, McMaster University, Hamilton, Ontario, Canada

12 (careysk@mcmaster.ca, shatilnj@mcmaster.ca)

$13{ }^{6}$ Department of Geosciences, Boise State University, Boise, Idaho, USA

14 (jmcnamar@boisestate.edu)

$15{ }^{7}$ Department of Forest Ecology and Management, Swedish University of Agricultural Sciences,

16 Umeå, Sweden (hjalmar.laudon@slu.se)

17 *Correspondence to: Matthias Sprenger (matthias.sprenger@abdn.ac.uk) 


\section{Abstract}

20 Quantifying soil water storage, mixing and release via recharge, transpiration and evaporation is

21 essential for a better understanding of critical zone processes. Here, we integrate stable isotope

$22\left({ }^{2} \mathrm{H}\right.$ and ${ }^{18} \mathrm{O}$ of soil water, precipitation, and groundwater) and hydrometric (soil moisture) data

23 from five long-term experimental catchments along a hydroclimatic gradient across northern

24 latitudes: Dry Creek (USA), Bruntland Burn (Scotland), Dorset (Canada), Krycklan (Sweden),

25 and Wolf Creek (Canada). Within each catchment, six to eleven isotope sampling campaigns

26 occurred at two to four sampling locations over at least one year. Analysis for ${ }^{2} \mathrm{H}$ and ${ }^{18} \mathrm{O}$ in the

27 bulk pore water was done for $>2500$ soil samples either by cryogenic extraction (Dry Creek) or

28 by direct equilibration (other sites). The results showed a similar general pattern that soil water

29 isotope variability reflected the seasonality of the precipitation input signal. However,

30 pronounced differences among sampling locations occurred regarding the isotopic fractionation

31 due to evaporation. We found that antecedent precipitation volumes mainly governed the

32 fractionation signal, temperature and evaporation rates were of secondary importance, and soil

33 moisture played only a minor role in the variability of soil water evaporation fractionation across

34 the hydro-climatic gradient. We further observed that soil waters beneath conifer trees were more

35 fractionated than beneath heather shrubs or red oak trees, indicating higher soil evaporation rates

36 in coniferous forests. Sampling locations closer to streams were more damped and depleted in

37 their stable isotopic composition than hillslope sites, revealing increased subsurface mixing

38 towards the saturated zone and a preferential recharge of winter precipitation. Bulk soil waters

39 generally comprised a high share of waters older than 14 days, which indicates that the water in

40 soil pores are usually not fully replaced by recent infiltration events. The presented stable isotope

41 data of soil water were, thus, a useful tool to track the spatial variability of water fluxes within 
1

2

3

4

5

6

7

8

9

10

11

12

13

14

15

16

17

18

19

20

21

22

23

24

25

26

27

28

29

30

31

32

33

34

35

36

37

38

39

40

41

42

43

44

45

46

47

48

49

50

51

52

53

54

55

56

57

58

59

60
42 and from the critical zone. Such data provide invaluable information to improve the 43 representation of critical zone processes in spatially-distributed hydrological models. 
44 Keywords: Isotopes, Soil Hydrology, Fractionation, Northern Environments, Evaporation, 45 Critical Zone

46 Running head: Stable isotopes of soil waters in northern environments

\section{$47 \quad 1 \quad$ Introduction}

48 The critical zone is a key determinant of partitioning precipitation into evaporation, transpiration,

49 groundwater recharge, and soil water storage (Brooks et al., 2015). Investigating water storage,

50 mixing and release in the unsaturated soil between the atmosphere and groundwater is therefore

51 crucial for the understanding of processes and interactions within the hydrological cycle (Grant

$52 \&$ Dietrich, 2017). The function of the critical zone in providing water for vegetation growth and

53 recharging groundwater resources is increasingly relevant because of observed and projected

54 changes in rain and snow patterns due to climate change (Hartmann et al., 2013) and/or changes

55 in vegetation cover due to land management (Smith et al., 2016). Environments north of $40^{\circ} \mathrm{N}$

56 are projected to be most affected by a temperature increase due to climate change (Serreze \&

57 Barry, 2011), which can alter snow fall/melt dynamics, soil moisture and vegetation growth in

58 these regions (Holtmeier \& Broll, 2005; Xu et al., 2013). As these changes affect the water 59 dynamics of the critical zone in northern latitudes, there is an urgent need for a better 60 understanding of the hydrological processes involved (Tetzlaff et al., 2013).

61 The upper critical zone, as the interface between soil, vegetation and atmosphere, plays a key 62 role in mediating evapotranspiration and recharge dynamics. Consequently, as vegetation and 63 atmospheric drivers change, the physical understanding of how these drivers affect hydrological 64 processes are pivotal to assess future changes of the critical zone water balance (Brooks et al., 65 2015; Tetzlaff, Buttle, Carey, van Huijgevoort et al., 2015). 
66 Since predictions of such water balance changes in the critical zone are usually based on

67 hydrological models, we need a sound understanding of the relevant hydrological processes

68 involved to adequately conceptualise them in models in a physically realistic way (Clark et al.,

69 2016). In addition to the hydraulic response of a system, tracers such as stable isotopes of water

$70 \quad\left({ }^{2} \mathrm{H}\right.$ and $\left.{ }^{18} \mathrm{O}\right)$ are known to be particularly valuable, since they provide insight into the velocity of

71 water particles and transport (celerity, e.g., measured in soil moisture) processes (McDonnell \&

72 Beven, 2014). Accounting for flow velocities enables estimation of water ages (travel times,

73 residence times) in the critical zone, which are of particular interest for contamination transport

74 (e.g., Sprenger, Erhardt, Riedel, \& Weiler, 2016) and weathering rates (Maher, 2010). In this

75 regard, the common assumption in tracer-aided hydrological modelling that soils are well-mixed

76 systems is rarely the case in nature (Fenicia et al., 2010; McMillan, 2012), especially when

77 considering the influence of evapotranspiration on the age of runoff (van der Velde et al., 2015).

78 Previously, field data of stable isotopes of bulk soil water revealed that the water in the

79 unsaturated zone is of varying age (Sprenger, Seeger, Blume, \& Weiler, 2016) and that the soil

80 water isotope compositions vary markedly in near-surface soil where vegetation-atmosphere

81 interactions occur (see review by Sprenger, Leistert, Gimbel, \& Weiler, 2016). A global analysis

82 by Evaristo, Jasechko, and McDonnell (2015) confirmed that the northern latitudes have not

83 been extensively researched regarding soil water isotope dynamics. Recent work has provided

84 the first insights into isotopic signals into mobile (Geris, Tetzlaff, McDonnell, \& Soulsby, 2015;

85 Peralta-Tapia et al., 2016) and bulk soil waters (Geris, Tetzlaff, McDonnell, Anderson et al.,

86 2015; Geris, Tetzlaff, McDonnell, \& Soulsby, 2017; Sprenger, Tetzlaff, \& Soulsby, 2017a).

87 However, since these studies were limited to single catchments, comparison of how atmospheric

88 conditions and vegetation properties impact the storage, mixing and fluxes of water in the critical 
89 zone at different sites across the northern latitudes is still missing (Tetzlaff, Buttle, Carey,

90 McGuire et al., 2015). We address therefore the following open questions in our study:

91 - How do atmospheric conditions across a hydroclimatic gradient affect the dynamics of 92 the stable isotopic composition of soil waters?

93 - Which role do vegetation, topography and elevation play in storage, mixing and flux of $94 \quad$ water in the critical zone in northern environments?

95 Our objective is to bring together stable isotope data from five long-term experimental, higher

96 latitude catchments spanning a hydroclimatic gradient regarding their temperature and wetness.

97 We explain their soil water isotope variability in space and time in relation to the environmental

98 conditions. We further present differences and similarities in soil water mixing, percolation and

99 evaporation based on the isotopic signals in soil waters at sampling locations that differ in their 100 vegetation cover, topographic position and elevation. The comparative study reveals the potential 101 for stable isotopes to serve as a tracer to track water through the critical zone.

\section{Methods}

\section{$103 \quad 2.1 \quad$ Study sites}

104 The study sites are five long-term experimental catchments spanning a hydroclimatic gradient 105 across the northern latitudes: Dry Creek, Idaho, USA ( $\left.43^{\circ} 42^{\prime} \mathrm{N} 116^{\circ} 10^{\prime} \mathrm{W}\right)$, Bruntland Burn in

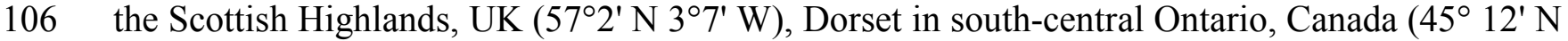
$\left.10778^{\circ} 49^{\prime} \mathrm{W}\right)$, Krycklan (sub-catchment C4) in northern Sweden (64 $14^{\prime} \mathrm{N} 19^{\circ} 46^{\prime} \mathrm{E}$ ), and Wolf 108 Creek in Yukon Territory, Canada $\left(60^{\circ} 32^{\prime} \mathrm{N} 135^{\circ} 18^{\prime} \mathrm{W}\right)$ (Figure 1). Within each catchment, we 109 sampled the soil water isotopic composition at two to four locations. The catchments are part of 110 the VeWa project (Vegetation effects on water flow and mixing in high-latitude ecosystems, 
111 https://www.abdn.ac.uk/geosciences/departments/geography-environment/vewa-908.php) and

112 their general hydroclimatic and isotopic characteristics have been compared in detail previously

113 (Tetzlaff, Buttle, Carey, van Huijgevoort et al., 2015). For the current study, we focus on the

114 description of the climate and the differences of the sampling locations regarding their soil, 115 vegetation and topographical features (Table 1).

116 Climatic conditions range from cold arid climate with dry summers (Bsk, according to the 117 updated Köppen-Geiger climate classification by Kottek, Grieser, Beck, Rudolf, and Rubel 118 (2006)) in Dry Creek, warm temperate fully humid climate with cool summers (Cfc) at 119 Bruntland Burn, to cold fully humid climates with either warm summers (Dfb) in Dorset or cold 120 summers (Dfc) in Krycklan, and a cold climate with dry and warm summers (Dsb) in Wolf 121 Creek. Thus, the catchments cover a wide range in air temperatures and precipitation amount. 122 Annual mean air temperature during the sampling period was highest at Dry Creek at $9.5^{\circ} \mathrm{C}$ and 123 lowest in Wolf Creek at about $0.7^{\circ} \mathrm{C}$. Annual precipitation ranges from $440 \mathrm{~mm}$ year ${ }^{-1}$ at Wolf 124 Creek to $1332 \mathrm{~mm} \mathrm{year}^{-1}$ at Bruntland Burn (Table 1).

125 The soils at Dry Creek are loam to sandy loam soils that developed on granite (Tesfa, Tarboton, 126 Chandler, \& McNamara, 2010). At Bruntland Burn, Dorset, and in the freely draining locations 127 at Krycklan and Wolf Creek, podzols have developed on glacial till. The near-stream sampling 128 locations, S04 at Krycklan and RP at Wolf Creek, have considerably higher organic matter 129 content and are classified at Histosols and Alluvium, respectively (Table 1). Soils at all sampling 130 locations are generally of coarse texture ranging between loamy or silty sands to sand (Table 1).

131 The vegetation cover at each sampling location is listed in Table 1. The Dry Creek locations 132 have a mixed vegetation cover, and the sampling locations at Bruntland Burn are either covered 133 with Scots pine (Pinus sylvestris) (NF and SF) or Erica species (Calluna vulgaris) (NH and SH). 
134 At Dorset, vegetation at three sampling locations is dominated by coniferous tree cover (Eastern

135 hemlock (Tsuga canadensis), Eastern white cedar (Thuja occidentalis), White pine (Pinus

136 strobus); He, Ce, Pw, respectively) and at one location (Or) by red oak (Quercus rubra). Norway

137 spruce (Picea abies) is dominant in low-lying areas and Scots pine (Pinus sylvestris) in upslope 138 areas at Krycklan, while birch (Betulaceae nana) and willow (Salix spec.) are dominant at Wolf 139 Creek.

140 Sampling locations are usually on hillslopes of low gradient, but both the S04 sampling location 141 in Krycklan and the RP sampling location in Wolf Creek are in the riparian zone with 142 groundwater levels $<30 \mathrm{~cm}$ (Table 1). Thus, S04 and RP provided a topographical contrast to the 143 upslope locations in the respective catchments: S22 at Krycklan and PL in Wolf Creek.

144 While the sampling locations within the Bruntland Burn, Dorset, Krycklan and Wolf Creek 145 catchments are at most few hundred metres from each other, the two locations in Dry Creek, one 146 at the catchment outlet (LG) and one at the tree line (TL) are approximately $5 \mathrm{~km}$ away from 147 each other and have an altitude difference of $600 \mathrm{~m}$ (Table 1).

148 Environmental conditions at the sampling locations allowed us to investigate the effects of 149 vegetation cover on the soil water isotopic composition at the Bruntland Burn and Dorset sites. 150 The topographical differences between the sites within the Krycklan and Wolf Creek catchments 151 allowed us to compare hillslope soil waters with soil waters in the riparian zone and the different 152 altitudes of the sampling locations at Dry Creek enabled comparison of elevation effects.

\section{$153 \quad 2.2 \quad$ Available data}

154 Soil sampling for the stable isotope analyses occurred between 6 and 11 times at each location 155 over at least one year (Table 2). Sampling during winter dormancy (leaf-off) took place only on a 
156 few occasions. The maximum sampling depths at the locations varied between $-20 \mathrm{~cm}$ at

157 Bruntland Burn and $-70 \mathrm{~cm}$ at Dry Creek and depended mainly on the accessibility of the soil 158 which decreased over depth with increasing rock content. At Bruntland Burn, Krycklan and 159 Dorset soil samples were taken in $5 \mathrm{~cm}$ intervals down to 20,30 or $50 \mathrm{~cm}$ depths, respectively. 160 At each depth five (Bruntland Burn and Krycklan) or four (Dorset) replicates within $10 \mathrm{~m}$ 161 distance were taken for every sampling campaign. However, due to the high rock content, it was 162 not always possible for four replicates to be taken at depths below $20 \mathrm{~cm}$ at the Dorset locations. 163 Sampling depths at Dry Creek were 10, 25, 45, and $70 \mathrm{~cm}$ and number of replicates varied 164 between 2 and 4 at each depth and sampling day due to varying rock contents. The sampling 165 depths at Wolf Creek varied between $2 \mathrm{~cm}$ for the shallowest and $40 \mathrm{~cm}$ for the deepest samples 166 and were therefore grouped into $10 \mathrm{~cm}$ intervals and the number of replicates varied between 1 167 and 3.

168 The stable isotopic compositions ${ }^{2} \mathrm{H}$ and ${ }^{18} \mathrm{O}$ of soil water was sampled with the direct169 equilibration method proposed by Wassenaar, Hendry, Chostner, and Lis (2008) for Bruntland 170 Burn, Dorset, Krycklan, and Wolf Creek. A detailed description of stable isotope analyses as 171 done at the University of Aberdeen for the European samples was presented by Sprenger, 172 Tetzlaff, and Soulsby (2017b) and for the Canadian samples analysed at the University of 173 Saskatchewan was described by Hendry, Schmeling, Wassenaar, Barbour, and Pratt (2015). The 174 general procedure for the direct-equilibration method was as follows: disturbed soil samples 175 were stored in sealed bags and dry air was added to the bag in the laboratory. During 2 or 3 days 176 (University of Aberdeen and Saskatchewan, respectively) of storage at constant temperature, an 177 isotopic equilibration between the soil water and the headspace developed and then the vapour of 178 the saturated headspace was sampled directly via laser spectrometry (TWIA-45-EP LGR). Bags 
179 with standard waters of known isotopic composition ranging the expected soil water isotopic 180 composition were also analysed the same way. These standard waters were used for calibration

181 to derive the isotopic composition of the liquid soil waters from the vapor measurements in 182 reference to the Vienna standard mean ocean water (VSMOW) as proposed by Wassenaar et al. 183 (2008). Water from soil samples taken at Dry Creek were cryogenically extracted at $100^{\circ} \mathrm{C}$ under 184 vacuum of $<30$ millitorr over 40 minutes (McCutcheon, McNamara, Kohn, \& Evans, 2016). The 185 accuracy of the direct-equilibration method was $\pm 0.31 \%$ for $\delta^{18} \mathrm{O}$ and $\pm 1.13 \%$ for $\delta^{2} \mathrm{H}$ 186 (Sprenger et al., 2017a) and $\pm 0.15 \%$ for $\delta^{18} \mathrm{O}$ and $\pm 0.69 \%$ for $\delta^{2} \mathrm{H}$ for the cryogenic extraction 187 (West, Patrickson, \& Ehleringer, 2006). Based on comparisons between the direct-equilibration 188 and cryogenic extraction method on field wetted silty to sandy soils (Orlowski, Pratt, Breuer, \& 189 McDonnell, 2017; Sprenger, Herbstritt, \& Weiler, 2015), we can assume that the differences 190 regarding the shape of the isotope depth profiles between these two methods are not significant.

191 The soil samples analysed with the direct-equilibration are more enriched in heavy isotopes than 192 the samples analysed with the cryogenic extraction. However, the differences plot along the 193 LMWL in a dual-isotope plot. Both analysis methods are not limited to sampling the mobile 194 water, but generally determine the stable isotopic composition of bulk soil water (Sprenger et al., 195 2015).

196 Along with the soil water sampling, precipitation and snow melt from lysimeters were sampled 197 for their isotopic composition at each catchment. Daily precipitation samples were available at 198 Bruntland Burn and Krycklan. Daily to fortnightly data were available at Dorset, Dry Creek, and 199 Wolf Creek. Snow melt was sampled at Dry Creek, Dorset, Krycklan, and Wolf Creek with snow 200 lysimeters. Snowmelt is not relevant at the Bruntland Burn site. Isotopic analyses of precipitation 201 and snow melt were done on a Los Gatos DLT-100 laser isotope analyser for Dorset and Wolf 
202 Creek, a Los Gatos Liquid Water Isotope Analyzer (LWIA) for Bruntland Burn and Dry Creek, 203 and on a Picarro L1102-i and L2130-I for Krycklan. The precision of the liquid water stable 204 isotope analysis is reported to be better than $\pm 0.1 \%$ for $\delta^{18} \mathrm{O}$ and $\pm 0.4 \%$ for $\delta^{2} \mathrm{H}$. All isotope 205 data are given in delta-notation (Coplen, 2011) in reference to the VSMOW.

206 We derived the local meteoric water line (LMWL) for each catchment, describing the linear 207 relationship between $\delta^{2} \mathrm{H}$ and $\delta^{18} \mathrm{O}$ values in precipitation samples as a regression line of slope $a$ 208 and the intercept $b: \delta^{2} \mathrm{H}=\mathrm{a} * \delta^{18} \mathrm{O}+\mathrm{b}$. Water samples plotting along the LMWL in a dual 209 isotope plot represent equilibrium fractionation (at 100\% humidity) as described by Majoube 210 (1971). Water samples located below the LMWL are indicative of non-equilibrium (kinetic) 211 fractionation, which occurs during evaporation in open systems at humidity below $100 \%$ (Gat \& 212 Gonfiantini, 1981). This deviation from the LMWL was defined by Landwehr and Coplen 213 (2006) as the line-conditioned excess (lc-excess) as follows: lc-excess $=\delta^{2} \mathrm{H}-\mathrm{a} * \delta^{18} \mathrm{O}-\mathrm{b}$, 214 using slope $a$ and intercept $b$ of the LMWL.

215 In addition to the isotope data, standard meteorological data including air temperature (T) and 216 precipitation amount $(\mathrm{P})$ were available at each catchment. Further, potential evapotranspiration 217 (PET) was estimated using the Penman-Monteith equation (Allen, Pereira, Raes, \& Smith, 1998). 218 From this, we generated mean values to characterize the hydro-meteorological conditions prior 219 to the soil sampling campaigns: $\mathrm{P}_{2}, \mathrm{P}_{7}, \mathrm{P}_{14}$, and $\mathrm{P}_{30}$ : sum of precipitation and snowmelt input 220 over $2,7,14$ and 30 days prior to soil sampling, respectively, $\mathrm{PET}_{30}$ : average potential 221 evapotranspiration 30 days prior to soil sampling, $\mathrm{T}_{30}$ : mean air temperature 30 days prior to soil 222 sampling, $\mathrm{DD}_{30}$ : number of dry days in 30 days prior to soil sampling. Regarding $\mathrm{T}_{30}, \mathrm{PET}_{30}$ and $223 \mathrm{DD}_{30}$, the time span of integration does not affect the analysis, as the 30-day indices correlate 
224 linearly with indices of time spans of 2,7 , or 14 days. As precipitation sums over $2,7,14$, or 30

225 days do not necessarily correlate, we tested in our analysis different integration periods.

226 Daily soil moisture data based on continuous soil moisture measurements at 10 or $15 \mathrm{~cm}$ soil 227 depth were available for each soil water sampling location at Bruntland Burn, Dry Creek, 228 Krycklan, and Wolf Creek (Figure S1), representing the soil water storage in the top soil. For 229 Dorset, where only a few manual soil moisture measurements were available, daily soil moisture 230 data were derived from soil physical modelling as shown by Sprenger, Tetzlaff, Buttle, Laudon, 231 Leistert et al. (2018). The volumetric soil moisture (VSM, $\left.\mathrm{cm}^{3} \mathrm{~cm}^{-3}\right)$ data were used to assess the 232 hydrologic state (e.g., wetness) on the days of individual sampling campaigns.

\section{$233 \quad 2.3 \quad$ Statistical analysis}

234 Comparisons between differences in soil water $\delta^{2} \mathrm{H}$ and lc-excess in the upper $10 \mathrm{~cm}$ and soil 235 below $10 \mathrm{~cm}$ were done with the Wilcoxon rank sum test (Hollander \& Wolfe, 1973) adjusting 236 p-values according to Holm (1979), as the data sets were not normally distributed according to 237 the Shapiro-Wilk test. We analysed linear relationships between average soil water $\delta^{2} \mathrm{H}, \delta^{18} \mathrm{O}$, or 238 1c-excess of the sampling sites and weighted average of $\mathrm{P} \delta^{2} \mathrm{H}, \mathrm{P} \delta^{18} \mathrm{O}$, or $\mathrm{P}$ lc-excess, 239 respectively, using Pearson correlation, as the data sets were normally distributed according to 240 the Shapiro-Wilk test. The same applied to relationships of average $\mathrm{P} \delta^{2} \mathrm{H}$ and $\mathrm{P} \delta^{18} \mathrm{O}$ with 241 average air temperature at the catchments. Spearman rank correlation was used for analysis of 242 relationships of soil water $\delta^{2} \mathrm{H}$ and lc-excess with $\mathrm{P}_{30}, \mathrm{~T}_{30}, \mathrm{VSM}$, and $\mathrm{P}_{30} \delta^{2} \mathrm{H}$ or $\mathrm{P}_{30}$ lc-excess, 243 respectively, at each site, as normality could not be assumed for all data sets based on the 244 Shapiro-Wilk test. 
245 We used multiple linear regression (MLR) to assess which variables explain the variance of the 246 soil water lc-excess over time (over a year, spring, summer, and autumn) and space (between 247 sampling locations). For the MLR, we derived mean values for each sampling location for lc248 excess in the top $30 \mathrm{~cm}$, as the upper $30 \mathrm{~cm}$ of soil has been shown to be most affected by 249 evaporation fractionation (Sprenger, Leistert et al., 2016). While the sampling depths were not 250 the same at Dry Creek and Wolf Creek as at the other sites, we still saw at all sites the highest 251 dynamics of lc-excess in the upper soil layer, which allowed inferring evaporation fractionation 252 from such data. Just like the lc-excess values, we calculated average values of the possible 253 predictors $\mathrm{P}_{2}, \mathrm{P}_{7}, \mathrm{P}_{14}, \mathrm{P}_{30}, \mathrm{~T}_{30}, \mathrm{PET}_{30}, \mathrm{DD}_{30}$, VSM for all sampling campaigns considered, and 254 data taken in spring, summer, and autumn, respectively. We reduced the number of possible 255 predictors to $\mathrm{P}_{7}, \mathrm{P}_{30}, \mathrm{~T}_{30}$, and VSM as correlation diagrams revealed collinearity of $\mathrm{T}_{30}$ with $256 \mathrm{PET}_{30}$ and $\mathrm{P}_{30}$ with $\mathrm{DD}_{30}$ (Figure S4, S5, S6, S7). Multiple linear regression analysis was then 257 applied (including interaction of the predictors) and non-significant predictors were discarded 258 subsequently to simplify the model. The significance of predictors was tested with ANOVA ( $\mathrm{p}<$ 259 0.05). The final MLR model only considered significant predictors. All the data used in the MLR 260 were standardized to account for differences in the units and ranges of the predictors (z-scores 261 transformation). We also tested whether using logarithmic or exponential transformation of 262 variables improved the regression fit. The soil water lc-excess data were reciprocally 263 transformed for the MLR conducted on the entire data set and the subset of summer samples to 264 get normal distributions. The autumn data was not normally distributed and also transformation 265 did not result in normal distribution of lc-excess values. The relative importance of the 266 explanatory parameters in the MLR model were derived according to Grömping (2006). To 267 visualize relationships between potentially non-linear and/or statistically non-significant trends, 
268 we added LOWESS (Locally Weighted Scatterplot Smoothing) curves to scatter plots 269 (Cleveland, 1979).

270 We used Pearson correlation to assess the relationships between soil water $\delta^{2} \mathrm{H}$ at different 271 depths and the weighted precipitation $\delta^{2} \mathrm{H}$ values integrated over 2, 7, 14 and 30 days, 272 respectively, as the hypothesis of the data being normally distributed could not be rejected 273 (Shapiro-Wilk test). The average weighted precipitation input over 30 days prior to the sampling 274 showed highest correlation, which is why we also provide the slope of the regression for soil 275 water $\delta^{2} \mathrm{H}$ at different depths and $\mathrm{P}_{30}$ input $\delta^{2} \mathrm{H}$ compositions.

\section{Results}

\section{$277 \quad 3.1 \quad$ Stable isotope dynamics in soil waters across a hydroclimatic gradient}

\section{$278 \quad$ 3.1.1 Variability at each sampling location}

279 Soil water isotopic composition $\left(\delta^{2} \mathrm{H}\right.$ and $\left.\delta^{18} \mathrm{O}\right)$ across the five catchments reflected the isotopic 280 composition of the local precipitation input (P) (Figure 2,

281 Table 2). The average soil water $\delta^{2} \mathrm{H}$ and $\delta^{18} \mathrm{O}$ values in the upper $30 \mathrm{~cm}$ at each sampling 282 location correlated significantly with the corresponding weighted average of precipitation $(\mathrm{r}=$ 2830.94 and $\mathrm{r}=0.92$, respectively, and both $\mathrm{p}<0.001)$. The weighted average of $\mathrm{P} \delta^{2} \mathrm{H}$ was related 284 to the annual average air temperature across the hydroclimatic gradient between Bruntland Burn, 285 Dorset, Krycklan and Wolf Creek $(\mathrm{r}=0.98, \mathrm{p}=0.02)$. The precipitation isotope data from Dry 286 Creek were excluded for this correlation, as precipitation mainly falls during winter leading to 287 depleted average precipitation/snow melt isotope compositions similar to Krycklan, despite the 288 air temperature being on average $\sim 5^{\circ} \mathrm{C}$ warmer in Dry Creek (Table 1). 
289 The seasonality of $\mathrm{P} \delta^{2} \mathrm{H}$ and $\mathrm{P} \delta^{18} \mathrm{O}$ was imprinted in the sampled soil water isotope depth 290 profiles (Figure S2). The soil water $\delta^{2} \mathrm{H}$ profiles showed more depleted values between late 291 autumn and early spring compared to sampling campaigns during summer and early fall that 292 were generally more enriched. The soil water $\delta^{2} \mathrm{H}$ and $\delta^{18} \mathrm{O}$ of the upper $30 \mathrm{~cm}$ at the individual 293 sampling locations showed limited relationships with the potential explanatory variables: $\delta^{2} \mathrm{H}$ $294 \mathrm{P}_{30}, \mathrm{P}_{30}, \mathrm{~T}_{30}$, VSM (Table S1). Soil water lc-excess dynamics at the individual sampling locations 295 also could not be related to lc-excess $\mathrm{P}_{30}, \mathrm{P}_{30}, \mathrm{~T}_{30}$, or VSM (Table $\mathrm{S} 1$ ).

296 At all sites, the top $10 \mathrm{~cm}$ were significantly more enriched in both $\delta^{2} \mathrm{H}$ and $\delta^{18} \mathrm{O}$ compared to 297 soil water below $10 \mathrm{~cm}$ (Figure 2b). Soil waters in the top $10 \mathrm{~cm}$ often plotted below the LMWL 298 and the lc-excess showed that the evaporation signal was significantly more pronounced in the 299 top $10 \mathrm{~cm}$ than below $10 \mathrm{~cm}$ at Bruntland Burn, Dorset and Dry Creek during the growing season 300 when evaporative demand was highest (between mid-May and end of September, Figure 3).

301 Evaporative enrichment of the soil water isotopes, given as lc-excess, was highest and most 302 dynamic in the top soil (Figure 2, Figure S3). The lc-excess usually decreased with soil depth 303 leading to regression lines in the dual isotope space with varying slopes over the seasons and 304 among sampling locations (Figure 4). The slopes of these regression lines were generally lower 305 than the slopes of the LMWL. The relationship between the average lc-excess in the upper $30 \mathrm{~cm}$ 306 of soil and the average PET over 30 days prior to the sampling $\left(\mathrm{PET}_{30}\right)$ revealed that the lc307 excess was not necessarily lowest during highest evaporative demand (summer), but lc-excess 308 was lowest after the peak $\mathrm{PET}_{30}$ (Figure 5). Thus, soil waters were still highly fractionated just 309 before the dormant season started. These patterns in lc-excess dynamics indicate that there is a 310 memory effect regarding the evaporation fractionation in the soil waters. The relationship 311 between lc-excess and $\mathrm{PET}_{30}$ was not necessarily linear, but there was a time lag with spring 
312 sampling campaigns often resulting in highest lc-excess (closest to the slope of the LMWL as

313 shown in Figure 4), even though $\mathrm{PET}_{30}$ values were already as high as during the autumn

314 samples (Figure 5).

\section{$315 \quad$ 3.1.2 Variability across sampling locations}

316 Average soil water $\delta^{2} \mathrm{H}$ and $\delta^{18} \mathrm{O}$ values of the upper $30 \mathrm{~cm}$ at each sampling location could not

317 be explained in terms of corresponding antecedent temperature $\mathrm{T}_{30}$, evaporative demand $\mathrm{PET}_{30}$

318 or VSM $\left(\mathrm{r}<0.14\right.$, not shown). Antecedent precipitation volumes $\mathrm{P}_{30}$ showed significant

319 correlation with soil water $\delta^{2} \mathrm{H}$ and $\delta^{18} \mathrm{O}$ values across locations $(\mathrm{r}=0.66$ and $\mathrm{r}=0.58$,

320 respectively). However, the relatively dry summers in Wolf Creek and Dry Creek (relative to the

321 wetter locations at Bruntland Burn, Dorset and Krycklan), where the depleted snow melt and

322 spring precipitation is stored in the soil over the summer, appear to drive this relationship, rather

323 than a causal relationship between precipitation volumes and soil water isotopes.

324 Average soil water lc-excess in the upper $30 \mathrm{~cm}$ at the sampling locations generally correlated

325 significantly with corresponding $\mathrm{P}_{30}$ and $\mathrm{T}_{30}$ (Figure 6). When limiting the data to spring, none of

326 the predictors showed a significant correlation with soil water lc-excess. For the summer

327 sampling dates, only $\mathrm{P}_{30}$ showed a significant relationship with soil water lc-excess, while the lc-

328 excess of autumn samples had a significant correlation to $\mathrm{P}_{30}$ and $\mathrm{T}_{30}$. VSM did not show a

329 significant linear relationship with soil water lc-excess (Figure 6).

330 To assess the relative importance of controlling variables potentially explaining the soil water lc-

331 excess across the sampling locations, multiple linear regression was applied to the pooled data

332 sets. Results showed that $\mathrm{P}_{7}$ explained $100 \%$ of the variation in soil water lc-excess when all

333 data was considered(Table 3). Soil water lc-excess during spring was mainly explained by $\mathrm{P}_{7}$

$334(81 \%)$ and partially by $\mathrm{T}_{30}(19 \%) .83 \%$ of soil water lc-excess variability during summer could 
335 be explained by $\mathrm{P}_{30}$, while $\mathrm{T}_{30}$ explained $17 \%$. Most important in explaining the soil water lc336 excess in autumn was the combined effect of $\mathrm{T}_{30}$ and VSM (35\%) and both $\mathrm{P}_{30}$ and $\mathrm{T}_{30}$ 337 explained about $26 \%$, while VSM accounted for $9 \%$ and the combination of $\mathrm{P}_{30}$ and $\mathrm{T}_{30}$ 338 explained just $3 \%$ (Table 3). Using logarithmic or exponential transformations for the multiple 339 linear regression did not improve the regression fit.

\section{$340 \quad 3.2 \quad$ Effects of vegetation}

341 Vegetation cover had a significant effect on the soil water isotopic composition at the Bruntland 342 Burn sampling locations, which were of similar soil texture. Soil water beneath Scots pine was 343 generally more enriched in heavy isotopes (median \pm standard deviation $\delta^{2} \mathrm{H}=-50.9 \pm 10.6 \%$, 344 1c-excess $=-3.6 \pm 4.7 \%$ o $)$ than soil water beneath heather $\left(\delta^{2} \mathrm{H}=-52.4 \pm 9.9 \%\right.$, lc-excess $=-$ $3452.3 \pm 3.6 \%$ ). The vegetation effect on soil water $\delta^{2} \mathrm{H}$ was statistically significant in the upper 10 $346 \mathrm{~cm}$, where 80 to $90 \%$ of the fine roots are located (Figure $7 \mathrm{a}$ ). Regarding the lc-excess, the 347 evaporation signal was significantly more pronounced beneath Scots pine compared to soils 348 beneath heather, across the upper $15 \mathrm{~cm}$ of the profile (Figure $7 \mathrm{~b}$ ).

349 At Dorset, the soil water $\delta^{2} \mathrm{H}$ beneath broad-leaved trees (Red oaks, $\delta^{2} \mathrm{H}=-52.2 \pm 12.1 \%$ ) were 350 not significantly different to soil water beneath conifer trees $\left(\delta^{2} \mathrm{H}:-53.4 \pm 10.6 \%\right)$ and soil water $351 \delta^{2} \mathrm{H}$ did not show a consistent pattern in the comparison between the two landscape units across 352 the soil profile (Figure 7c). However, the soil water lc-excess in the upper $50 \mathrm{~cm}$ was 353 significantly lower beneath conifers (lc-excess $=-4.1 \pm 6.3 \%$ ) than beneath broad-leaved trees 354 (lc-excess: $-2.0 \pm 6.5 \%$ ). The lc-excess values were consistently more negative beneath the 355 conifers across the soil profile, but significant differences were limited to $10-15,15-20$, and 25 $35630 \mathrm{~cm}$ sampling depths (Figure 7d). 


\section{$357 \quad 3.3 \quad$ Effect of topography}

358 Soil waters of sampling locations in the riparian zone at Krycklan and Wolf Creek were 359 generally more depleted in heavy isotopes compared to the nearby upslope locations. Soil waters 360 at S04 were significantly more depleted in $\delta^{2} \mathrm{H}(-88.2 \pm 5.1 \%)$ than at $\mathrm{S} 22\left(\delta^{2} \mathrm{H}=-80.5 \pm 8.4 \%\right)$.

361 The soil water isotopes at S04 were more depleted and of lower variability at all sampled depths 362 compared to S22 (Figure 8a). In terms of 1c-excess values, the soil waters at S04 and S22 did not 363 differ significantly; neither for the entire upper $30 \mathrm{~cm}$ (lc-excess $=-0.6 \pm 2.3 \%$ and lc-excess $=-$ $3640.9 \pm 2.8 \%$, respectively), nor for any depth of the sampled profiles, with the exception of 20-30 $365 \mathrm{~cm}$ (Figure 8b).

366 At Wolf Creek, RP was significantly more depleted in its soil water $\delta^{2} \mathrm{H}$ composition ($367159.8 \pm 8.8 \%)$ compared to the PL location $\left(\delta^{2} \mathrm{H}=-154.6 \pm 11.2 \%\right)$. The differences across the 368 soil profile were significant for the $30-40 \mathrm{~cm}$ depth interval, but the PL median soil water $\delta^{2} \mathrm{H}$ 369 values were generally more enriched across the entire profile and showed higher variability 370 (Figure 8c). Similar to the Krycklan locations, the soil water lc-excess did not differ significantly 371 (PL 1c-excess $-5.5 \pm 15.2 \%$ and RP 1c-excess $-8.3 \pm 13.7 \%$ ) across the upper $40 \mathrm{~cm}$ nor at any 372 particular depth.

\section{$373 \quad 3.4 \quad$ Effect of elevation}

374 Soil water isotopes at the lower elevation site in Dry Creek, LG, were significantly more 375 enriched in heavy isotopes than the higher elevation site at tree line, TL $\left(\delta^{2} \mathrm{H}=-118.1 \pm 12.4 \%\right.$ o 376 and $\delta^{2} \mathrm{H}=-125.3 \pm 14.1 \%$, respectively). Across the soil profile, the TL soil waters were 377 consistently depleted in $\delta^{2} \mathrm{H}$ compared to $\mathrm{LG}$, but these differences were not statistically 378 significant (Figure 9a). However, the soil water lc-excess values were generally significantly 
379 different between the two locations, with median values of $-15.0 \pm 17.0 \%$ at the LG location and $380-8.5 \pm 17.7 \%$ at TL. Median lc-excess values at each sampled soil depth were more negative at 381 LG than at TL (Figure 9b).

\section{$382 \quad 3.5 \quad$ Mixing processes in the subsurface}

383 We infer mixing processes from correlation analysis between soil water $\delta^{2} \mathrm{H}\left(\delta_{\mathrm{sw}}\right)$ dynamics and

384 weighted averages of the precipitation/snow melt $\delta^{2} \mathrm{H}$ signal prior to the sampling $\left(\delta_{\mathrm{P}}\right)$. The 385 relationship between $\delta_{\mathrm{SW}}$ and $\delta_{\mathrm{P}}$ generally decreased with depth at Bruntland Burn, Dorset, 386 Krycklan, and Wolf Creek (Figure 10). There was usually no correlation of $\delta_{\mathrm{SW}}$ with the most 387 recent infiltrated water $\left(\mathrm{P}_{2}\right)$. Also the infiltrating water over a week prior to the soil water 388 sampling showed little correlation with $\delta_{\mathrm{SW}}$ and was often limited to the upper 5 to $10 \mathrm{~cm}$. At 389 Bruntland Burn and S22, correlation between $\delta_{\mathrm{SW}}$ and $\delta_{\mathrm{P} 30}$ was generally high $(\mathrm{r}>0.6)$. 390 However, at the S04 location, this relationship decreased sharply within the upper $20 \mathrm{~cm}$ and was 391 absent $(\mathrm{r}=0)$ at $20-30 \mathrm{~cm}$ depth. At the Dorset locations and PL at Wolf Creek, the relationship 392 between stable isotopic composition in precipitation and soil water dropped below $25 \mathrm{~cm}$ soil 393 depth. At Wolf Creek RP and the Dry Creek locations, no relationship between antecedent 394 precipitation input and soil water response was evident.

395 These correlation analyses reveal that the soil waters were mainly composed of a mixture of 396 older (more than two weeks) infiltrated waters. This is supported by the relatively low slopes of 397 the regression between $\delta_{\mathrm{SW}}$ and $\delta_{\mathrm{P} 30}$. The soil water isotopic compositions were generally more 398 depleted in heavy isotopes than the infiltrating water $(\mathrm{m}<1)$, which means that the soils pore 399 waters were dominated by isotopically depleted water infiltrated during winter or snow melt. For 400 all sites, this regression slope generally decreased over the upper $30 \mathrm{~cm}$ soil depth (Figure 10). 
401 At the top $5 \mathrm{~cm}$ of soil at the Bruntland Burn locations, the soil waters were closest to $\mathrm{P}_{30}$, while

402 the riparian zone locations, very rich in organic material, had generally low regression slopes

403 between $\delta_{\mathrm{SW}}$ and $\delta_{\mathrm{P} 30}$. (S04 between 0.2 and 0 ; RP about zero). Also at Dry Creek, where very

404 little precipitation falls during summer and autumn, the slopes were close to zero, but partly $<0$.

\section{Discussion}

\section{$406 \quad 4.1$ Hydro-meteorological controls on the stable isotopic composition of soil waters}

407 Our results for the northern latitudes underline that the soil-vegetation-atmosphere interface is a 408 crucial area that needs to be incorporated at sufficiently fine resolution in soil water sampling 409 designs to understand water transport and mixing processes through the critical zone. As all sites 410 at the long-term experimental catchments had a significantly different soil water $\delta^{2} \mathrm{H}\left(\right.$ and $\left.\delta^{18} \mathrm{O}\right)$ 411 signal in the top $10 \mathrm{~cm}$ compared to the soil waters below $10 \mathrm{~cm}$, our study highlights the 412 importance of the upper critical zone as an important interface. The sampling depths and 413 sampling intervals over depth strongly influenced the interpretation of the soil water isotope data, 414 since intense interactions between soil, vegetation and atmosphere take place in the upper critical 415 zone. Our results showed that isotopic fractionation in the bulk soil water was highest within the 416 top $10 \mathrm{~cm}$ of the soil, which has important implications for ecohydrological studies when relating 417 the isotopic compositions of soil waters to plant waters to estimate root water uptake depths (see 418 review by Rothfuss and Javaux (2017)). Missing the highly fractionated soil waters of the top 419 soil, where fine root densities are often highest (Jackson et al., 1996; Zeng, 2001), can potentially 420 lead to misinterpretations in ecohydrological studies. As previously shown for Dry Creek and 421 Bruntland Burn, the isotope fractionation (lc-excess $<0)$ can reach down to $70 \mathrm{~cm}(\mathrm{McCutcheon}$ 422 et al., 2016) or be limited to the upper $15 \mathrm{~cm}$ (Sprenger et al., 2017a), respectively. However, an 
423 explanation of the temporal variability of the soil water lc-excess signal at the individual 424 catchments was impeded by the limited range of both the soil water isotopic signals and the 425 explanatory variables at each of the sites (Table S1).

426 Our study, therefore, benefitted from the unique data setof several sampling locations of varying 427 hydro-meteorological conditions, which provided an opportunity to analyse the factors driving 428 the temporal variability of soil water fractionation signals. While soil water $\delta^{2} \mathrm{H}$ and $\delta^{18} \mathrm{O}$ values 429 were generally related to the respective input signal of precipitation, the dual isotope approach of 430 using the lc-excess that describes the ratio between $\delta^{2} \mathrm{H}$ and $\delta^{18} \mathrm{O}$ revealed new insights into the 431 isotopic fractionation due to soil evaporation. In line with findings by Hsieh, Chadwick, Kelly, 432 and Savin (1998), the kinetic fractionation of stable isotopes in soil water was negatively 433 correlated with precipitation sums and positively correlated with potential evaporation rates. 434 However, our multiple linear regression analysis revealed the relative importance of different 435 explanatory variables. We found that neither potential evaporation $\left(\mathrm{PET}_{30}\right)$ nor air temperature $436\left(\mathrm{~T}_{30}\right)$ were the most important factors to explain the lc-excess variability over time and space at 437 the different sampling locations. Instead, antecedent precipitation $\left(\mathrm{P}_{7}\right)$ explained the variability 438 of soil water lc-excess values for the entire data set. Also for the spring and summer sampling 439 campaigns, the recent infiltration volumes $\left(\mathrm{P}_{7}\right)$ for spring and the infiltration over the previous 440 month $\left(\mathrm{P}_{30}\right)$ for summer were with $80 \%$ the most important factors. Thus, while soil evaporation 441 is necessary for kinetic fractionation of the soil water (lc-excess $<0$ ), the fractionation signal will 442 be diluted by newly un-fractionated precipitation input $($ lc-excess $=0)$. Such a dependency of the 443 fractionation signal on precipitation input was also shown for bulk soil waters in south-central 444 Chile, where the soil water lc-excess values approached zero during the rainy season (Hervé445 Fernández et al., 2016). 
446 Soil moisture only affected the lc-excess signal for the autumn sampling campaigns. Therefore,

447 when evaporation rates decreased and little further fractionation took place in autumn, the

448 volume of the stored water had an influence on the evaporation signal of the stable isotope

449 compositions: The dilution of the evaporation signal established mainly during summer is slower

450 for soils that have higher soil moisture contents in autumn. That the dilution of the isotopic

451 fractionation signal took time - or more appropriately, needed more cumulative precipitation

452 input - is shown by the fact that the lc-excess of the soil waters in the upper $30 \mathrm{~cm}$ were lowest

453 after the peak evaporation at all sites (Figure 5). Thus, the soil water isotopic fractionation

454 dynamics lagged the evaporation dynamics, resulting in a "memory effect" in the soil water of

455 the upper layer. Our data therefore supports recent theoretical considerations by Benettin et al.

456 (2018) that soil water isotopic compositions are most fractionated in autumn due to mixing of

457 waters. This has important implications for ecohydrological studies, as this implies that the soil

458 water is highly enriched during the plant water uptake just before dormancy of the vegetation.

459 This could potentially explain isotopically enriched xylem waters sampled after dormancy, as

460 presented by McCutcheon et al. (2016). Due to the interplay between transient soil moisture

461 content, fractionating evaporation output and fractionation-diluting precipitation input, there is

462 no linear relation between soil evaporation and the kinetic fraction signal of the bulk soil waters.

463 This lagged response of the bulk soil waters, not only to precipitation/snow melt infiltration, but 464 also soil evaporation losses, is in strong contrast to the relatively quick response in the waters of 465 the more mobile water, sampled with suction lysimeters at Bruntland Burn, Dorset, and Krycklan 466 (Sprenger, Tetzlaff, Buttle, Laudon, Leistert et al., 2018). Thus, an ecohydrological separation, 467 where mobile soil waters are isotopically different from bulk soil waters (Brooks, Barnard, 468 Coulombe, \& McDonnell, 2010), is probably linked to different water ages. As our results show, 
469 the soil pores between 5 and $25 \mathrm{~cm}$ depth are usually composed of waters older than at least two 470 weeks and will therefore be obviously different from recently infiltrated water, sampled with 471 suction lysimeters. Latest simulations with a soil physical model underlined that the median 472 water ages in the upper $10 \mathrm{~cm}$ of soil at the Bruntland Burn, Dorset and Krycklan sites vary 473 between few days and up to 50 days during the growing season (Sprenger, Tetzlaff, Buttle, 474 Laudon, \& Soulsby, 2018).

\subsection{The role of vegetation, topography and elevation for storage, mixing and flux of water in the critical zone}

477 The soil water isotope data from the five different catchments provide insights into some of the 478 ways how the vegetation cover, topography and elevation influence the soil water isotope 479 composition. Regarding the vegetation influences found at Bruntland Burn and Dorset, the 480 impact of an altered infiltration signal due to isotopic fractionation of the throughfall can be 481 excluded as a comparison between stable isotopes of throughfall and gross rainfall did not show 482 a significant offset at these sites (Soulsby, Braun, Sprenger, Weiler, \& Tetzlaff, 2017, Snelgrove, 483 unpublished data, 2017). As isotopic fractionation was generally higher for the soil waters 484 beneath the Scots pines compared to the soils beneath heather at Bruntland Burn, these 485 differences can be related to less dense canopy cover, lower humidity, and higher soil486 atmosphere vapor exchange in the forest (Sprenger et al., 2017a). Similarly, Zhang, An, Xu, Cui, 487 and $\mathrm{Xu}$ (2011) also related higher atmospheric humidity due to vegetation cover to decreased 488 isotopic fractionation of soil waters. At Dorset, lc-excess was lower beneath the coniferous trees 489 than beneath the broadleaf Red oak, despite limited differences between the two vegetation types 490 in terms of canopy cover. However, the vegetation influence on the evaporation signal at both 491 Bruntland Burn and Dorset sites was limited to the top soil with no significant differences below $49215 \mathrm{~cm}$ and $30 \mathrm{~cm}$, respectively. Thus, variability of the isotopic signal across the soil profile was 
493 most intense in the upper layers of the unsaturated zone where the soil-vegetation-atmosphere

494 interactions take place.

495 The topographic influences between hillslope and riparian zone on $\delta^{2} \mathrm{H}$ values were consistent at 496 Krycklan and Wolf Creek. At both catchments, soil waters closer to the stream were less variable 497 and generally more depleted in $\delta^{2} \mathrm{H}$ compared to the soil water on the hillslopes. These findings 498 indicate greater mixing of different flow paths and waters of different ages in the subsurface 499 towards the riparian zone, confirming their "isostat" behaviour described in Tetzlaff, Birkel, 500 Dick, Geris, and Soulsby (2014). This interpretation corresponds with other studies where a 501 lower variability of the stable isotope composition in soil waters in time (Asano, Uchida, \& Ohte, 502 2002) or over the soil depth (Garvelmann, Külls, \& Weiler, 2012) was associated with greater 503 mixing towards the stream. In fact, isotopic composition of soil waters at the riparian zone 504 locations, S04 and RP, appeared to be disconnected from the isotopically variable precipitation 505 input $(\mathrm{r}<0.2$ below $15 \mathrm{~cm}$ soil depth, Figure 10$)$. Since the $\delta^{2} \mathrm{H}$ values at these locations are 506 generally more depleted than the incoming precipitation (regression slopes $\delta_{\mathrm{SW}}^{2}$ and $\delta^{2}{ }_{\mathrm{P} 30}<0.2$, 507 Figure 10), we saw that depleted winter precipitation or snow melt is preferably recharging the 508 riparian zone. Hence, seasonal root water uptake during the growing season affects the long-term 509 isotope balance of the critical zone, which eventually governs the groundwater isotopic 510 composition (slightly above the LMWL, Figure 4). Additionally, the high organic matter content 511 at S04 and RP results in high pore volumes, which affect the mixing processes in the riparian 512 soils.

513 Our soil water samples at the plot scale support the interpretation of catchment scale isotope 514 studies in northern latitudes and/or regions with snow cover that the most intense recharge of 515 groundwater occurs from waters depleted in heavy isotopes such as snow melt (Dry Creek, 
516 Dorset, Krycklan, Wolf Creek) and winter rainfall (Bruntland Burn) (Jasechko, Wassenaar, \& 517 Mayer, 2017; Scheliga, Tetzlaff, Nuetzmann, \& Soulsby, 2017; Sprenger, Tetzlaff, Tunaley, 518 Dick, \& Soulsby, 2017; Zapata-Rios et al., 2015). At Dry Creek, the soil pores get filled during 519 the snow melt in early spring and this melt water stays in the soil over the summer, since little 520 precipitation occurs then. Therefore, stable isotopic composition does not show a relationship to 521 the isotopic composition of antecedent precipitation input (Figure 10). Because of this intense 522 seasonality of precipitation/snow melt input at Dry Creek, mixing of soil waters with newly 523 introduced precipitation during summer is little, leading to high fractionation of the isotopes in 524 the soil water (Figure 3). Our data from northern environments showed no differences between 525 soil waters in the riparian zone and the hillslope regarding their evaporation fractionation signal. 526 In contrast, Simonin et al. (2014) showed that the uppermost $(0-5 \mathrm{~cm})$ soil layer was more 527 isotopically fractionated at the hillslopes compared to the valley bottom in a Mediterranean 528 environment.

529 The effect of elevation on the isotopic signal of precipitation is well documented (e.g., Ambach, 530 Dansgaard, Eisner, \& Moller, 1968) and this altitude effect for the Dry Creek catchment was 531 approximately $1.8 \%$ depletion in $\delta^{2} \mathrm{H}$ per $100 \mathrm{~m}$ elevation (Tappa, Kohn, McNamara, Benner, 532 \& Flores, 2016). This difference of the precipitation input signal between LG and TL is reflected 533 in the soil water $\delta^{2} \mathrm{H}$ depth profiles (Figure 9a). The lc-excess depth profiles are significantly 534 different for the two sampling locations, with higher fractionated isotopic composition at the 535 lower sampling location indicating higher soil evaporation losses. Due to the extended dry 536 periods and relatively high temperatures during summer, the soil water fractionation extends to $53770 \mathrm{~cm}$ depth. Therefore, contrary to the effect of vegetation, the elevation effect is not limited to 538 the upper $30 \mathrm{~cm}$, but results in significant differences in lc-excess values through the deeper soil 
539 profile. We explain these differences in soil water lc-excess in terms of longer snow free periods,

540 higher evaporation, and less precipitation at LG compared to TL (Table 1).

541 The various controls on the soil water isotopic composition emphasise the spatial in addition to 542 the temporal variability in $\delta^{2} \mathrm{H}, \delta^{18} \mathrm{O}$, and lc-excess of waters within the critical zone. These 543 varying isotopic signals result from different processes such as increased mixing along longer 544 flow paths (advection-dispersion) or soil evaporation in varying landscape units. Such 545 information can be used to calibrate (Sprenger, Seeger et al., 2016) or validate (Mueller et al., 546 2014) water flow and transport simulations with soil physical models at the profile or the 547 hillslope scale (Windhorst, Kraft, Timbe, Frede, \& Breuer, 2014). Stable isotope data of the 548 water in the critical zone of representative landscape units can further increase the physical 549 realism of spatially distributed tracer-aided catchment models (Soulsby et al., 2015; van 550 Huijgevoort, Tetzlaff, Sutanudjaja, \& Soulsby, 2016). Regarding such modelling approaches, 551 crucially, the presented data can also help to assess water age dynamics in the critical zone, as 552 the dampening of the highly variable precipitation isotope compositions over the soil depth can 553 be related to the travel time (DeWalle, Edwards P.J., Swistock B.R., Aravena R., \& Drimmie 554 R.J, 1997). It has been shown in several studies that this damping happens mostly within the 555 upper $30 \mathrm{~cm}$ (reviewed in Sprenger, Leistert et al., 2016). Usually, the isotopic signal of mobile 556 water (sampled with lysimeters) is used for travel time analysis in the soil (e.g., Muñoz-Villers \& 557 McDonnell, 2012; Tetzlaff et al., 2014; Timbe et al., 2014). The data presented here are bulk soil 558 water isotopes including pore waters of potentially older ages compared to mobile waters that 559 were shown to have only little to no isotopic fractionation at Bruntland Burn (Geris, Tetzlaff, 560 McDonnell, \& Soulsby, 2015), Dorset (Sprenger, Tetzlaff, Buttle, Laudon, Leistert et al., 2018) 561 and Krycklan (Peralta-Tapia, Sponseller, Tetzlaff, Soulsby, \& Laudon, 2015). Considering the 
562 above discussed impacts of vegetation, topography and elevation on the bulk soil water isotopic 563 compositions, we can expect that such processes will affect the age dynamics of the soil waters, 564 resulting in different travel time estimates than limiting the analysis to the mobile water phase 565 (Sprenger, Tetzlaff, Buttle, Laudon, \& Soulsby, 2018).

\section{Conclusion}

567 Stable isotope data of bulk soil waters at various locations in five catchments spanning a wide 568 range of hydro-meteorological conditions in northern latitude environments, provided a unique 569 insight into storage, mixing and release of waters within the upper critical zone. We showed the 570 benefits of examining a suite of data sets to cover a wider range of both response variables (e.g. 571 lc-excess in top $30 \mathrm{~cm}$ ) and predictors (e.g., $\mathrm{P}_{7}, \mathrm{P}_{30}, \mathrm{~T}_{30}, \mathrm{VSM}$ ). While it is expected that higher 572 temperatures lead to higher soil evaporation that kinetically fractionates the soil water isotopes, 573 mixing with infiltrated precipitation that is un-fractionated was found to be the dominant driver 574 of the soil water lc-excess signal amongst the 14 sampling locations. The resulting memory 575 effect in the isotopic compositions results in an evaporation fractionation of soil waters that is 576 most intense during autumn. The observed lag between isotopic evaporation signal in the soil 577 water and the evaporation rates lead to pronounced isotopic fractionation signals in the soil just 578 before vegetation dormancy. This can have important consequences for the interpretation of 579 ecohydrological studies relating the isotopic composition of soil and vegetation water dependent 580 on the timing and frequency of the sampling: Our findings underscore the need of sampling the 581 shallow soils as they are most dynamic as well as considering the seasonal variability of soil 582 water isotope compositions and their hydro-meteorological drivers.

583 We further showed that there are common effects of vegetation cover on the evaporation signal 584 of soil water with more pronounced differences between soils beneath Scots pine and heather 
585 than between conifers and Red oaks. Topography was also found to affect soil water isotopes, 586 indicating more mixing and greater contributions of older water towards stream channels.

587 However, also in shallow soil layers, the presented bulk water generally comprised waters older 588 than 14 days. This indicates that the pore water is usually not fully replaced by recent infiltration 589 events, but bulk and mobile soil waters are probably of different isotopic composition and thus 590 represent different water ages. In general, integration of such spatially variable stable isotope 591 data can help resolve the partitioning of precipitation in the upper soil zone and improve 592 estimates of travel times or root water uptake depths of the critical zone.

\section{Acknowledgements}

594 We thank Audrey Innes for isotope analysis at University of Aberdeen for Bruntland Burn and 595 Krycklan sites, Johannes Tiwari (SLU) for isotope sampling in Krycklan, Pernilla Löfvenius 596 (SLU) for providing PET data for Krycklan (via SITES), and Jeff McDonnell and Kim Janzen 597 (University of Saskatchewan) for soil water isotope analysis for the Dorset and Wolf Creek sites. 598 The Krycklan part was funded by the KAW Branch-Point project. We acknowledge the funding 599 from the European Research Council (ERC, project GA 335910 VeWa). We thank the Editor and 600 three anonymous reviewers for their critical comments during the peer-review process. 


\section{Figures}

602 Figure 1 Map of each of the five long-term experimental catchments showing the soil sampling

603 (black stars) locations, the elevation and the rivers. The location of each catchment is indicated

604 with the points on the world map (taken from: https://commons.wikimedia.org).

605 Figure 2 Dual isotope plots showing precipitation (left) and soil water (right) isotope data at the 606 five long-term experimental catchments (colour code). The soil water samples are split into 607 samples taken in the upper $10 \mathrm{~cm}$ (shown in dark with black contour colours in box plots and as 608 triangles in dual isotope plot) and below $10 \mathrm{~cm}$ (bright colours in box with grey lines in box plots 609 and circles in dual isotope plot). Note that the samples in the upper $10 \mathrm{~cm}$ for all sites are 610 significantly more enriched in heavy isotopes compared to the samples below (Mann-Whitney-U 611 test, $\mathrm{p}<0.05)$.

612 Figure 3 Soil water lc-excess between mid-May and end of September (growing season at the 613 study sites) for each site divided into samples from the upper $10 \mathrm{~cm}$ (black lines and dark 614 colours) and below $10 \mathrm{~cm}$ soil depth (bright colours and grey lines). The stars indicate significant 615 differences between the subset at each site (Mann-Whitney-U test, $\mathrm{p}<0.05)$.

616 Figure 4 Dual isotope plot for each study site showing all soil water samples for different seasons 617 (colour code). Regression lines through the samples for each sampling day are shown. Black 618 lines show the GMWL and the dashed lines show the LMWL for the individual catchments. 619 Black squares indicate the long-term groundwater signal (no data for Dorset).

620 Figure 5 Time series of the average potential evapotranspiration over the 30 days prior to the 621 sampling ( $\mathrm{PET}_{30}$, dashed lines) and the average lc-excess of the soil samples in the upper $30 \mathrm{~cm}$. 622 All data are unity-based normalized to get values between 0 (minimum value) and 1 (maximum 
623 value). Note that the axis of lc-excess is inverted and that a smaller value of lc-excess indicates

624 higher kinetic fractionation.

625 Figure 6 Relationship between soil water lc-excess signal in the upper $30 \mathrm{~cm}$ of soil with the 626 precipitation sum over 30 days prior to each sampling $\left(\mathrm{P}_{30}, 1^{\text {st }}\right.$ column $)$, the average temperature 627 over the 30 days prior each sampling $\left(\mathrm{T}_{30}, 2^{\text {nd }}\right.$ column), and the volumetric soil moisture (VSM, $6283^{\text {rd }}$ column $)$ for all samples $\left(1^{\text {st }}\right.$ row $)$ and for the samples taken in spring $\left(2^{\text {nd }}\right.$ row $)$, summer $\left(3^{\text {rd }}\right.$ 629 row), and autumn ( $4^{\text {th }}$ row). Colours represent the catchments and the marker style represent the 630 sampling locations within individual catchments. Coefficient of determinations $\left(\mathrm{r}^{2}\right)$ are given, 631 linear best-fit lines are shown for significant regressions $(p<0.05)$ and locally weighted 632 regressions (LOWESS filter) are plotted as dashed line.

633 Figure 7 Effects of vegetation on the soil water isotopes with examples from Bruntland Burn (a 634 and b) and Dorset (c and d). Points represent the individual samples and the violin plots show the 635 distribution as a kernel density estimation of the soil water (a and c) $\delta^{2} \mathrm{H}$ and (b and d) lc-excess. 636 The vertical dashed lines within the violin plots represent the $25^{\text {th }}, 50^{\text {th }}$, and $75^{\text {th }}$ quartiles. " $X "$ 637 next to the violin plots indicates significant differences between vegetation types (Paired 638 Wilcoxon rank sum test, $\mathrm{p}<0.05)$.

639 Figure 8 Effects of topography on soil water isotopes with example from Krycklan (a) and b)) 640 and Wolf Creek (c) and d)). Points represent the individual samples and the violin plots show the 641 distribution as a kernel density estimation of the soil water (a and c) $\delta^{2} \mathrm{H}$ and (b and d) lc-excess. 642 The vertical dashed lines within the violin plots represent the $25^{\text {th }}, 50^{\text {th }}$, and $75^{\text {th }}$ quartiles. " $X$ " 643 next to the violin plots indicates significant differences between slope positions (Paired 
644 Wilcoxon rank sum test, $\mathrm{p}<0.05$ ). Note, for Wolf Creek, only sampling days in parallel were 645 considered and depth intervals were constructed.

646 Figure 9 Effects of altitude on soil water isotopes with example from Dry Creek. Points represent 647 the individual samples and the violin plots show the distribution as a kernel density estimation of 648 the soil water (a) $\delta^{2} \mathrm{H}$ and (b) lc-excess. The vertical dashed lines within the violin plots 649 represent the $25^{\text {th }}, 50^{\text {th }}$, and $75^{\text {th }}$ quartiles. " $\mathrm{X}$ " next to the violin plots indicates significant 650 differences between altitudes (Paired Wilcoxon rank sum test, $\mathrm{p}<0.05$ ).

651 Figure 10 Correlation coefficient $r$ of the relationship between the soil water $\delta^{2} \mathrm{H}$ at different 652 depths and the 2-, 7-, 14-, and 30-day weighted average precipitation or snowmelt $\delta^{2} \mathrm{H}$ input $\left(\mathrm{P}_{2}\right.$, $653 \mathrm{P}_{7}, \mathrm{P}_{14}, \mathrm{P}_{30}$, respectively). For $\mathrm{P}_{30}$, also the slope of the regression between soil water $\delta^{2} \mathrm{H}$ and $\mathrm{P}_{30}$ 654 is given. The color code represents the scale between -1 and 1 as given in the color bar on the 655 bottom left. 
658 Table 1 Environmental characteristics of each study site: Average values of precipitation sum

659 (P), air temperature (T), potential evapotranspiration (PET), and number of dry days for 12

660 months during the sampling period (Table 2); soil type, soil texture description, vegetation cover, 661 elevation and groundwater depth at the sampling locations within the five long-term 662 experimental catchments. $\mathrm{OM}=$ organic matter content.

663 Table 2 Isotope sampling design (number of sampling campaigns, sampling period, maximum 664 sampling depth, and total sample number), mean volumetric soil moisture at $10 \mathrm{~cm}$ (VSM) and 665 isotopic characteristics of the precipitation $(\mathrm{P})$ and soil waters in the upper $30 \mathrm{~cm}$.

666 Table 3 Results of multiple linear regression models to explain the soil water lc-excess data 667 pooled for each sampling site over different time periods: all available data, spring, summer, and 668 autumn (as shown in Figure 6). The significance level for each parameter is given according to 669 ANOVA of the linear models. $* * *=p<0.001 ; * *=p<0.01 ; *=p<0.05, \stackrel{\bullet}{*}=\mathrm{p}<0.10$, n.s. indicates 670 parameters that were not significant for the model. Percentage in brackets show the relative 671 importance of the explanatory parameter. Note that the lc-excess data was reciprocally 672 transformed for "All data" and "Summer" to get normal distributions and that the lc-excess of 673 the samples taken in autumn was not normally distributed. 


\section{References}

675 Allen, R. G., Pereira, L. S., Raes, D., \& Smith, M. (1998). Crop evapotranspiration-Guidelines 676 for computing crop water requirements-FAO Irrigation and drainage paper 56. FAO, Rome, $677 \quad 300(9)$, D05109.

678 Ambach, W., Dansgaard, W., Eisner, H., \& Moller, J. (1968). The altitude effect on the isotopic 679 composition of precipitation and glacier ice in the Alps. Tellus, 20(4), 595-600. $680 \quad$ https://doi.org/10.1111/j.2153-3490.1968.tb00402.x

681 Asano, Y., Uchida, T., \& Ohte, N. (2002). Residence times and flow paths of water in steep 682 unchannelled catchments, Tanakami, Japan. Journal of Hydrology, 261(1-4), 173-192. 683 https://doi.org/10.1016/S0022-1694(02)00005-7

684 Benettin, P., Volkmann, T. H. M., Freyberg, J. von, Frentress, J., Penna, D., Dawson, T. E., \& 685 Kirchner, J. W. (2018). Effects of climatic seasonality on the isotopic composition of 686 evaporating soil waters. Hydrol. Earth Syst. Sci. Discuss., 1-16. https://doi.org/10.5194/hess$687 \quad 2018-40$

688 Brooks, J. R., Barnard, H. R., Coulombe, R., \& McDonnell, J. J. (2010). Ecohydrologic 689 separation of water between trees and streams in a Mediterranean climate. Nature Geoscience, 690 3(2), 100-104. https://doi.org/10.1038/NGEO722

691 Brooks, P. D., Chorover, J., Fan, Y., Godsey, S. E., Maxwell, R. M., McNamara, J. P., \& Tague, 692 C. (2015). Hydrological partitioning in the critical zone: Recent advances and opportunities 693 for developing transferrable understanding of water cycle dynamics. Water Resources 694 Research, 51(9), 6973-6987. https://doi.org/10.1002/2015WR017039 
695 Clark, M. P., Schaefli, B., Schymanski, S. J., Samaniego, L., Luce, C. H., Jackson, B. M., Freer, 696 J. E., Arnold, J. R., Moore, R. D.,.. Ceola, S. (2016). Improving the theoretical 697 underpinnings of process-based hydrologic models. Water Resources Research, 52(3), 2350698 2365. https://doi.org/10.1002/2015WR017910

699 Cleveland, W. S. (1979). Robust locally weighted regression and smoothing scatterplots. Journal $700 \quad$ of the American statistical association, 74(368), 829-836.

701 Coplen, T. B. (2011). Guidelines and recommended terms for expression of stable-isotope-ratio 702 and gas-ratio measurement results. Rapid Communications in Mass Spectrometry, 25(17), $703 \quad 2538-2560$. https://doi.org/10.1002/rcm.5129

704 DeWalle, D.R., Edwards P.J., Swistock B.R., Aravena R., \& Drimmie R.J. (1997). Seasonal 705 isotope hydrology of three Appalachian forest catchments. Hydrological Processes, 11, 18957061906. https://doi.org/10.1002/(SICI)1099-1085(199712)11:15<1895::AID-

$707 \quad$ HYP538>3.0.CO;2-\#

708 Evaristo, J., Jasechko, S., \& McDonnell, J. J. (2015). Global separation of plant transpiration 709 from groundwater and streamflow. Nature, 525(7567), 91-94. 710 https://doi.org/10.1038/nature14983

711 Fenicia, F., Wrede, S., Kavetski, D., Pfister, L., Hoffmann, L., Savenije, H. H. G., \& McDonnell, 712 J. J. (2010). Assessing the impact of mixing assumptions on the estimation of streamwater 713 mean residence time. Hydrological Processes, 24(12), 1730-1741. 714 https://doi.org/10.1002/Hyp.7595

715 Garvelmann, J., Külls, C., \& Weiler, M. (2012). A porewater-based stable isotope approach for 716 the investigation of subsurface hydrological processes. Hydrology and Earth System Sciences, 717 16(2), 631-640. https://doi.org/10.5194/hess-16-631-2012 
718 Gat, J. R., \& Gonfiantini, R. (Eds.). (1981). Stable Isotope Hydrology: Deuterium and Oxygen71918 in the Water Cycle. Technical Report Series. Vienna, Austria: IAEA.

720 Geris, J., Tetzlaff, D., McDonnell, J., Anderson, J., Paton, G., \& Soulsby, C. (2015). 721 Ecohydrological separation in wet, low energy northern environments? A preliminary 722 assessment using different soil water extraction techniques. Hydrological Processes, 29(25), 723 5139-5152. https://doi.org/10.1002/hyp.10603

724 Geris, J., Tetzlaff, D., McDonnell, J., \& Soulsby, C. (2015). The relative role of soil type and 725 tree cover on water storage and transmission in northern headwater catchments. Hydrological 726 Processes, 29(7), 1844-1860. https://doi.org/10.1002/hyp.10289

727 Geris, J., Tetzlaff, D., McDonnell, J. J., \& Soulsby, C. (2017). Spatial and temporal patterns of 728 soil water storage and vegetation water use in humid northern catchments. The Science of the 729 total environment, 595, 486-493. https://doi.org/10.1016/j.scitotenv.2017.03.275

730 Grant, G. E., \& Dietrich, W. E. (2017). The frontier beneath our feet. Water Resources Research, 731 53(4), 2605-2609. https://doi.org/10.1002/2017WR020835

732 Grömping, U. (2006). Relative Importance for Linear Regression in R: The Package relaimpo. 733 Journal of Statistical Software, 17(1). https://doi.org/10.18637/jss.v017.i01

734 Hartmann, D. L., Klein Tank, A.M.G., Rusticucci, M., Alexander, L. V., Brönnimann, S., 735 Charabi, Y., Dentener, F. J., Dlugokencky, E. J., Easterling, D. R.,... Zhai, P. M. (2013). 736 Observations: Atmosphere and Surface. In T. F. Stocker, D. Qin, G.-K. Plattner, M. Tignor, S. 737 K. Allen, J. Boschung,... P. M. Midgley (Eds.), Climate Change 2013: The Physical Science 738 Basis.: Contribution of Working Group I to the Fifth Assessment Report of the 739 Intergovernmental Panel on Climate Change. Cambridge, United Kingdom and New York, 740 NY, USA: Cambridge University Press. 
741 Hendry, M. J., Schmeling, E., Wassenaar, L. I., Barbour, S. L., \& Pratt, D. (2015). Determining 742 the stable isotope composition of pore water from saturated and unsaturated zone core: 743 improvements to the direct vapour equilibration laser spectrometry method. Hydrol. Earth 744 Syst. Sci., 19(11), 4427-4440. https://doi.org/10.5194/hess-19-4427-2015

745 Hervé-Fernández, P., Oyarzún, C., Brumbt, C., Huygens, D., Bodé, S., Verhoest, N. E. C., \& 746 Boeckx, P. (2016). Assessing the "two water worlds" hypothesis and water sources for native 747 and exotic evergreen species in south-central Chile. Hydrological Processes, 30(23), 4227748 4241. https://doi.org/10.1002/hyp.10984

749 Hollander, M., \& Wolfe, D. A. (1973). Nonparametric Statistical Methods. New York: John $750 \quad$ Wiley \& Sons.

751 Holm, S. (1979). A simple sequentially rejective multiple test procedure. Scandinavian Journal 752 of Statistics, 6, 65-70.

753 Holtmeier, F.-K., \& Broll, G. (2005). Sensitivity and response of northern hemisphere altitudinal 754 and polar treelines to environmental change at landscape and local scales. Global Ecology and 755 Biogeography, 14(5), 395-410. https://doi.org/10.1111/j.1466-822x.2005.00168.x

756 Hsieh, J. C. C., Chadwick, O. A., Kelly, E. F., \& Savin, S. M. (1998). Oxygen isotopic 757 composition of soil water: Quantifying evaporation and transpiration. Geoderma, 82(1-3), 758 269-293. https://doi.org/10.1016/S0016-7061(97)00105-5

759 Jackson, R. B., Canadell, J., Ehleringer, J. R., Mooney, H. A., Sala, O. E., \& Schulze, E. D. 760 (1996). A global analysis of root distributions for terrestrial biomes. Oecologia, 108(3), 389761 411. https://doi.org/10.1007/BF00333714 
762 Jasechko, S., Wassenaar, L. I., \& Mayer, B. (2017). Isotopic evidence for widespread cold763 season-biased groundwater recharge and young streamflow across central Canada. 764 Hydrological Processes, 31(12), 2196-2209. https://doi.org/10.1002/hyp.11175

765 Kottek, M., Grieser, J., Beck, C., Rudolf, B., \& Rubel, F. (2006). World Map of the Köppen766 Geiger climate classification updated. Meteorologische Zeitschrift, 15(3), 259-263. 767 https://doi.org/10.1127/0941-2948/2006/0130

768 Landwehr, J. M., \& Coplen, T. B. (2006). Line-conditioned excess: a new method for 769 characterizing stable hydrogen and oxygen isotope ratios in hydrologic systems. In 770 International Conference on Isotopes in Environmental Studies (pp. 132-135). Vienna: IAEA.

771 Maher, K. (2010). The dependence of chemical weathering rates on fluid residence time. Earth 772 and Planetary Science Letters, 294(1-2), 101-110. https://doi.org/10.1016/j.eps1.2010.03.010

773 Majoube, M. (1971). Fractionnement en oxygene-18 et en deuterium entre l'eau et sa vapeur. $J$. $774 \quad$ Chim. phys, 68(10), 1423-1436.

775 McCutcheon, R. J., McNamara, J. P., Kohn, M. J., \& Evans, S. L. (2016). An Evaluation of the 776 Ecohydrological Separation Hypothesis in a Semiarid Catchment. Hydrological Processes, 777 31(4), 783-799. https://doi.org/10.1002/hyp.11052

778 McDonnell, J. J., \& Beven, K. (2014). Debates-The future of hydrological sciences: A (common) 779 path forward? A call to action aimed at understanding velocities, celerities and residence time 780 distributions of the headwater hydrograph. Water Resources Research, 50(6), 5342-5350. 781 https://doi.org/10.1002/2013WR015141

782 McMillan, H. K. (2012). Effect of spatial variability and seasonality in soil moisture on drainage 783 thresholds and fluxes in a conceptual hydrological model. Hydrological Processes, n/a. 784 https://doi.org/10.1002/hyp.9396 
785 Mueller, M. H., Alaoui, A., Kuells, C., Leistert, H., Meusburger, K., Stumpp, C., Weiler, M., \& 786 Alewell, C. (2014). Tracking water pathways in steep hillslopes by $\delta^{18} \mathrm{O}$ depth profiles of soil 787 water. Journal of Hydrology, 519(A), 340-352. https://doi.org/10.1016/j.jhydrol.2014.07.031

788 Muñoz-Villers, L. E., \& McDonnell, J. J. (2012). Runoff generation in a steep, tropical montane 789 cloud forest catchment on permeable volcanic substrate. Water Resources Research, 48(9), $790 \quad$ W09528. https://doi.org/10.1029/2011WR011316

791 Orlowski, N., Pratt, D., Breuer, L., \& McDonnell, J. J. (2017). Critical Evaluation of Soil Pore 792 Water Extraction Methods on a Natural Soil. In European Geoscience Union (Ed.): Vol. 19. 793 Geophysical Research Abstracts, EGU General Assembly 2017 (EGU2017-9905). Vienna.

794 Peralta-Tapia, A., Soulsby, C., Tetzlaff, D., Sponseller, R., Bishop, K., \& Laudon, H. (2016). 795 Hydroclimatic influences on non-stationary transit time distributions in a boreal headwater 796 catchment. Journal of Hydrology, 543(Part A), 7-16. 797 https://doi.org/10.1016/j.jhydrol.2016.01.079

798 Peralta-Tapia, A., Sponseller, R. A., Tetzlaff, D., Soulsby, C., \& Laudon, H. (2015). Connecting 799 precipitation inputs and soil flow pathways to stream water in contrasting boreal catchments. $800 \quad$ Hydrological Processes, 29(16), 3546-3555. https://doi.org/10.1002/hyp.10300

801 Rothfuss, Y., \& Javaux, M. (2017). Reviews and syntheses: Isotopic approaches to quantify root 802 water uptake: a review and comparison of methods. Biogeosciences, 14(8), 2199-2224. 803 https://doi.org/10.5194/bg-14-2199-2017

804 Scheliga, B., Tetzlaff, D., Nuetzmann, G., \& Soulsby, C. (2017). Groundwater isoscapes in a 805 montane headwater catchment show dominance of well-mixed storage. Hydrological 806 Processes, 31(20), 3504-3519. https://doi.org/10.1002/hyp.11271 
807 Serreze, M. C., \& Barry, R. G. (2011). Processes and impacts of Arctic amplification: A research 808 synthesis. Global and Planetary Change, 77(1-2), 85-96. 809 https://doi.org/10.1016/j.gloplacha.2011.03.004

810 Simonin, K. A., Link, P., Rempe, D., Miller, S., Oshun, J., Bode, C., Dietrich, W. E., Fung, I., \& 811 Dawson, T. E. (2014). Vegetation induced changes in the stable isotope composition of near 812 surface humidity. Ecohydrology, 7(3), 936-949. https://doi.org/10.1002/eco.1420

813 Smith, P., House, J. I., Bustamante, M., Sobocká, J., Harper, R., Pan, G., West, P. C., Clark, J. 814 M., Adhya, T.,... Pugh, T. A. M. (2016). Global change pressures on soils from land use and 815 management. Global change biology, 22(3), 1008-1028. https://doi.org/10.1111/gcb.13068

816 Soulsby, C., Birkel, C., Geris, J., Dick, J., Tunaley, C., \& Tetzlaff, D. (2015). Stream water age 817 distributions controlled by storage dynamics and nonlinear hydrologic connectivity: Modeling 818 with high-resolution isotope data. Water Resources Research, 51(9), 7759-7776. 819 https://doi.org/10.1002/2015WR017888

820 Soulsby, C., Braun, H., Sprenger, M., Weiler, M., \& Tetzlaff, D. (2017). Influence of forest and 821 shrub canopies on precipitation partitioning and isotopic signatures. Hydrological Processes, 822 31(24), 4282-4296. https://doi.org/10.1002/hyp.11351

823 Sprenger, M., Seeger, S., Blume, T., \& Weiler, M. (2016). Travel times in the vadose zone: 824 variability in space and time. Water Resources Research, 52(8), 5727-5754. 825 https://doi.org/10.1002/2015WR018077

826 Sprenger, M., Erhardt, M., Riedel, M., \& Weiler, M. (2016). Historical tracking of nitrate in 827 contrasting vineyards using water isotopes and nitrate depth profiles. Agric Ecosyst Environ 828 (Agriculture, Ecosystems \& Environment), 222, 185-192. 829 https://doi.org/10.1016/j.agee.2016.02.014 
830 Sprenger, M., Herbstritt, B., \& Weiler, M. (2015). Established methods and new opportunities

831 for pore water stable isotope analysis. Hydrological Processes, 29(25), 5174-5192.

832 https://doi.org/10.1002/hyp.10643

833 Sprenger, M., Leistert, H., Gimbel, K., \& Weiler, M. (2016). Illuminating hydrological processes

834 at the soil-vegetation-atmosphere interface with water stable isotopes. Reviews of Geophysics, 835 54(3), 674-704. https://doi.org/10.1002/2015RG000515

836 Sprenger, M., Tetzlaff, D., Buttle, J. M., Laudon, H., Leistert, H., Mitchell, C. P. J., Snelgrove, 837 J., Weiler, M., \& Soulsby, C. (2018). Measuring and modelling stable isotopes of mobile and 838 bulk soil water. Vadose Zone Journal. Advance online publication. 839 https://doi.org/10.2136/VZJ2017.08.0149

840 Sprenger, M., Tetzlaff, D., Buttle, J., Laudon, H., \& Soulsby, C. (2018). Water ages in the 841 critical zone of long-term experimental sites in northern latitudes. Hydrol. Earth Syst. Sci. 842 Discuss., 1-26. https://doi.org/10.5194/hess-2018-144

843 Sprenger, M., Tetzlaff, D., \& Soulsby, C. (2017a). Soil water stable isotopes reveal evaporation 844 dynamics at the soil-plant-atmosphere interface of the critical zone. Hydrology and Earth 845 System Sciences, 21(7), 3839-3858. https://doi.org/10.5194/hess-21-3839-2017

846 Sprenger, M., Tetzlaff, D., \& Soulsby, C. (2017b). No influence of CO2 on stable isotope 847 analyses of soil waters with OA-ICOS. Rapid Communications in Mass Spectrometry, 31(5), 848 430-436. https://doi.org/10.1002/rcm.7815

849 Sprenger, M., Tetzlaff, D., Tunaley, C., Dick, J., \& Soulsby, C. (2017). Evaporation fractionation 850 in a peatland drainage network affects stream water isotope composition. Water Resources 851 Research, 53(1), 851-866. https://doi.org/10.1002/2016WR019258 
852 Tappa, D. J., Kohn, M. J., McNamara, J. P., Benner, S. G., \& Flores, A. N. (2016). Isotopic 853 composition of precipitation in a topographically steep, seasonally snow-dominated watershed 854 and implications of variations from the Global Meteoric Water Line. Hydrological Processes, 855 30(24), 4582-4592. https://doi.org/10.1002/hyp.10940

856 Tesfa, T. K., Tarboton, D. G., Chandler, D. G., \& McNamara, J. P. (2010). A Generalized 857 Additive Soil Depth Model for a Mountainous Semi-Arid Watershed Based Upon 858 Topographic and Land Cover Attributes. In J. L. Boettinger, D. W. Howell, A. C. Moore, A. 859 E. Hartemink, \& S. Kienast-Brown (Eds.), Digital Soil Mapping: Bridging Research, 860 Environmental Application, and Operation (pp. 29-41). Dordrecht: Springer Netherlands. 861 https://doi.org/10.1007/978-90-481-8863-5_3

862 Tetzlaff, D., Birkel, C., Dick, J., Geris, J., \& Soulsby, C. (2014). Storage dynamics in 863 hydropedological units control hillslope connectivity, runoff generation and the evolution of 864 catchment transit time distributions. Water Resources Research, 50(2), 969-985. $865 \quad$ https://doi.org/10.1002/2013WR014147

866 Tetzlaff, D., Buttle, J., Carey, S. K., McGuire, K., Laudon, H., \& Soulsby, C. (2015). Tracer867 based assessment of flow paths, storage and runoff generation in northern catchments: a 868 review. Hydrological Processes, 29(16), 3475-3490. https://doi.org/10.1002/hyp.10412

869 Tetzlaff, D., Buttle, J., Carey, S. K., van Huijgevoort, M. H. J., Laudon, H., McNamara, J., 870 Mitchell, C. P. J., Spence, C., Gabor, R. S., \& Soulsby, C. (2015). A preliminary assessment 871 of water partitioning and ecohydrological coupling in northern headwaters using stable 872 isotopes and conceptual runoff models. Hydrological Processes, 29(25), 5153-5173. 873 https://doi.org/10.1002/hyp.10515 
874 Tetzlaff, D., Carey, S., Soulsby, C., Tetzlaff, D., Soulsby, C., Buttle, J., Capell, R., Carey, S. K., 875 Laudon, H.,. . Shanley, J. (2013). Catchments on the cusp? Structural and functional change 876 in northern ecohydrology. Hydrological Processes, 27(5), 766-774. 877 https://doi.org/10.1002/hyp.9700

878 Timbe, E., Windhorst, D., Crespo, P., Frede, H.-G., Feyen, J., \& Breuer, L. (2014). 879 Understanding uncertainties when inferring mean transit times of water trough tracer-based 880 lumped-parameter models in Andean tropical montane cloud forest catchments. Hydrology 881 and Earth System Sciences, 18(4), 1503-1523. https://doi.org/10.5194/hess-18-1503-2014

882 van der Velde, Y., Heidbüchel, I., Lyon, S. W., Nyberg, L., Rodhe, A., Bishop, K., \& Troch, P. 883 A. (2015). Consequences of mixing assumptions for time-variable travel time distributions. 884 Hydrological Processes, 29(16), 3460-3474. https://doi.org/10.1002/hyp.10372

885 van Huijgevoort, M. H. J., Tetzlaff, D., Sutanudjaja, E. H., \& Soulsby, C. (2016). Using high 886 resolution tracer data to constrain water storage, flux and age estimates in a spatially 887 distributed rainfall-runoff model. Hydrological Processes, 30(25), 4761-4778. $888 \quad$ https://doi.org/10.1002/hyp.10902

889 Wassenaar, L.I., Hendry, M.J., Chostner, V.L., \& Lis, G.P. (2008). High Resolution Pore Water $890 \quad \delta^{2} \mathrm{H}$ and $\delta^{18} \mathrm{O}$ Measurements by $\mathrm{H} 2 \mathrm{O}$ (liquid) $-\mathrm{H} 2 \mathrm{O}$ (vapor) Equilibration Laser 891 Spectroscopy. Environmental Science \& Technology, 42(24), 9262-9267. $892 \quad$ https://doi.org/10.1021/es802065s

893 West, A. G., Patrickson, S. J., \& Ehleringer, J. R. (2006). Water extraction times for plant and 894 soil materials used in stable isotope analysis. Rapid Communications in Mass Spectrometry, 895 20(8), 1317-1321. https://doi.org/10.1002/rcm.2456 
896 Windhorst, D., Kraft, P., Timbe, E., Frede, H.-G., \& Breuer, L. (2014). Stable water isotope 897 tracing through hydrological models for disentangling runoff generation processes at the 898 hillslope scale. Hydrology and Earth System Sciences, 18(10), 4113-4127. 899 https://doi.org/10.5194/hess-18-4113-2014

900 Xu, L., Myneni, R. B., Chapin III, F. S., Callaghan, T. V., Pinzon, J. E., Tucker, C. J., Zhu, Z., 901 Bi, J., Ciais, P.,... Stroeve, J. C. (2013). Temperature and vegetation seasonality 902 diminishment over northern lands. Nature Climate Change, 3, 581-586. 903 https://doi.org/10.1038/nclimate1836

904 Zapata-Rios, X., McIntosh, J., Rademacher, L., Troch, P. A., Brooks, P. D., Rasmussen, C., \& 905 Chorover, J. (2015). Climatic and landscape controls on water transit times and silicate 906 mineral weathering in the critical zone. Water Resources Research, 51(8), 6036-6051. 907 https://doi.org/10.1002/2015WR017018

908 Zeng, X. (2001). Global Vegetation Root Distribution for Land Modeling. Journal of $909 \quad$ Hydrometeorology, $\quad 2(5), \quad 525-530 . \quad$ https://doi.org/10.1175/1525$910 \quad 7541(2001) 002<0525: G V R D F L>2.0 . C O ; 2$

911 Zhang, W., An, S., Xu, Z., Cui, J., \& Xu, Q. (2011). The impact of vegetation and soil on runoff 912 regulation in headwater streams on the east Qinghai-Tibet Plateau, China. CATENA, 87(2), 913 182-189. https://doi.org/10.1016/j.catena.2011.05.020 
Table 1: Environmental characteristics of each study site: Average values of precipitation sum (P), air temperature (T), potential evapotranspiration (PET), and number of dry days for 12 months during the sampling period (Table 2); soil type, soil texture description, vegetation cover, elevation and groundwater depth at the sampling locations within the five long-term experimental catchments. $\mathrm{OM}=$ organic matter content.

\begin{tabular}{|c|c|c|c|c|c|c|c|c|c|}
\hline Catchment & Location & $\begin{array}{c}\mathrm{P} \\
{[\mathrm{mm}} \\
\left.\text { year }^{-1}\right]\end{array}$ & $\begin{array}{c}\mathrm{T} \\
{\left[{ }^{\circ} \mathrm{C}\right]}\end{array}$ & $\begin{array}{l}\text { PET } \\
{\left[\mathrm{mm}^{-1}\right.} \\
\left.\text { year }^{-1}\right]\end{array}$ & $\begin{array}{c}\text { Dry } \\
\text { days } \\
\text { year }^{-1} \\
\end{array}$ & $\begin{array}{l}\text { Soil } \\
\text { texture }\end{array}$ & Vegetation cover & $\begin{array}{l}\text { Elevation } \\
\text { [m a.s.l.] }\end{array}$ & $\begin{array}{c}\text { Groundwater } \\
\text { depth } \\
{[\mathrm{m}]}\end{array}$ \\
\hline \multirow[t]{2}{*}{ Dry Creek } & LG & 496 & $9.5 \pm 9.1$ & 695 & 246 & \multirow{2}{*}{$\begin{array}{l}\text { Loam to } \\
\text { sandy } \\
\text { loam }\end{array}$} & $\begin{array}{c}\text { Ponderosa pine (Pinus } \\
\text { ponderosa) and Douglas-fir } \\
(\text { Pseudotsuga menziesii) }\end{array}$ & 1150 & $>2$ \\
\hline & $\mathrm{TL}$ & 787 & $8.1 \pm 9.5$ & 671 & 245 & & Willow dominated & 1610 & $>2$ \\
\hline \multirow{4}{*}{$\begin{array}{l}\text { Bruntland } \\
\text { Burn }\end{array}$} & $\mathrm{NF}$ & \multirow{4}{*}{1332} & \multirow{4}{*}{$7.2 \pm 4.7$} & \multirow{4}{*}{488} & \multirow{4}{*}{116} & \multirow{4}{*}{$\begin{array}{l}\text { Loamy } \\
\text { sand, } \\
\text { OM =5- } \\
20 \%\end{array}$} & \multirow{4}{*}{$\begin{array}{c}\text { Scots pine (Pinus sylvestris) } \\
\text { Erica species (Calluna } \\
\text { vulgaris) } \\
\text { Scots pine (Pinus sylvestris) } \\
\text { Erica species (Calluna } \\
\text { vulgaris) }\end{array}$} & 260 & $>0.5$ \\
\hline & & & & & & & & 260 & $>0.5$ \\
\hline & $\mathrm{SF}$ & & & & & & & 270 & $>1$ \\
\hline & $\mathrm{SH}$ & & & & & & & 270 & $>1$ \\
\hline \multirow{4}{*}{ Dorset } & Or & \multirow{4}{*}{1125} & \multirow{4}{*}{$6.7 \pm 11.1$} & \multirow{4}{*}{898} & \multirow{4}{*}{249} & \multirow{4}{*}{$\begin{array}{l}\text { Sandy } \\
\text { loam, OM } \\
=4 \%\end{array}$} & Red oak (Quercus rubra) & 365 & $>0.5$ \\
\hline & $\mathrm{He}$ & & & & & & $\begin{array}{c}\text { Eastern hemlock (Tsuga } \\
\text { canadensis) }\end{array}$ & 370 & $>0.5$ \\
\hline & $\mathrm{Ce}$ & & & & & & $\begin{array}{c}\text { Eastern white cedar (Thuja } \\
\text { occidentalis) }\end{array}$ & 365 & $>0.5$ \\
\hline & $\mathrm{Pw}$ & & & & & & White pine (Pinus strobus) & 365 & $>0.5$ \\
\hline \multirow{2}{*}{ Krycklan } & S04 & \multirow{2}{*}{687} & \multirow{2}{*}{$3.2 \pm 8.7$} & \multirow{2}{*}{462} & \multirow{2}{*}{249} & $\begin{array}{l}\text { Sand, OM } \\
=80 \%\end{array}$ & $\begin{array}{c}\text { Norway spruce (Picea } \\
\text { abies) }\end{array}$ & 267 & $>0.3$ \\
\hline & $\mathrm{S} 22$ & & & & & $\begin{array}{l}\text { Sand, OM } \\
\quad=5 \%\end{array}$ & Scots pine (Pinus sylvestris) & 270 & $>0.5$ \\
\hline \multirow[b]{2}{*}{ Wolf Creek } & PL & \multirow[b]{2}{*}{440} & \multirow[b]{2}{*}{$0.28 \pm 8.4$} & \multirow[b]{2}{*}{432} & \multirow[b]{2}{*}{280} & $\begin{array}{l}\text { Silty sand, } \\
\mathrm{OM}=7 \%\end{array}$ & Birch (Betulaceae nana) & 1440 & $0.6-2$ \\
\hline & $\mathrm{RP}$ & & & & & $\begin{array}{c}\text { Silty sand, } \\
\text { OM = } 70 \\
\%\end{array}$ & Willow (Salix spec.) & 1370 & $0.1-0.3$ \\
\hline
\end{tabular}


Table 2: Isotope sampling design (number of sampling campaigns, sampling period, maximum sampling depth, and total sample number), mean volumetric soil moisture at $10 \mathrm{~cm}(\mathrm{VSM})$ and isotopic characteristics of the precipitation (P) and soil waters in the upper $30 \mathrm{~cm}$.

\begin{tabular}{|c|c|c|c|c|c|c|c|c|c|}
\hline Site & Location & $\begin{array}{l}\text { Sampling } \\
\text { campaigns }\end{array}$ & $\begin{array}{l}\text { Sampling } \\
\text { period }\end{array}$ & $\begin{array}{c}\text { Max. } \\
\text { sampling } \\
\text { depth [cm] }\end{array}$ & $\begin{array}{c}\text { Total } \\
\text { sample } \\
\text { number }\end{array}$ & $\begin{array}{c}\mathrm{VSM} \\
{\left[\mathrm{cm}^{3} \mathrm{~cm}^{-3}\right]}\end{array}$ & $\begin{array}{c}\mathrm{P} \delta^{2} \mathrm{H} \\
{[\% o]}\end{array}$ & $\begin{array}{c}\text { Soil water } \\
\delta^{2} \mathrm{H} \\
{[\% \mathrm{o}]}\end{array}$ & $\begin{array}{c}\text { Soil water } \\
\text { lc-excess } \\
{[\% 0]}\end{array}$ \\
\hline \multirow{2}{*}{$\begin{array}{c}\text { Dry } \\
\text { Creek }\end{array}$} & LG & 9 & $\begin{array}{c}2011-06-29- \\
2012-09-13\end{array}$ & \multirow[b]{2}{*}{-70} & 119 & $0.25 \pm 0.08$ & $-105.2 \pm 25.0$ & $-118.1 \pm 12.4$ & $-18.1 \pm 18.0$ \\
\hline & $\mathrm{TL}$ & 7 & $\begin{array}{c}2011-08-11- \\
2012-09-07\end{array}$ & & 132 & $0.15 \pm 0.07$ & $-113.8 \pm 25.7$ & $-125 \pm 14.1$ & $-8.5 \pm 17.7$ \\
\hline \multirow{4}{*}{$\begin{array}{l}\text { Bruntland } \\
\text { Burn }\end{array}$} & $\mathrm{NF}$ & 11 & & & 215 & $0.46 \pm 0.05$ & \multirow{4}{*}{$-52.8 \pm 25.0$} & $-52.0 \pm 11.1$ & $-3.6 \pm 4.9$ \\
\hline & $\mathrm{NH}$ & 11 & $2015-09-29-$ & 20 & 218 & $0.33 \pm 0.03$ & & $-51.1 \pm 10.8$ & $-2.0 \pm 3.6$ \\
\hline & $\mathrm{SF}$ & 11 & $2016-09-23$ & & 214 & $0.46 \pm 0.05$ & & $-50.5 \pm 10.2$ & $-3.7 \pm 4.5$ \\
\hline & $\mathrm{SH}$ & 11 & & & 211 & $0.33 \pm 0.03$ & & $-53.1 \pm 8.9$ & $-2.7 \pm 3.6$ \\
\hline \multirow{4}{*}{ Dorset } & Or & 6 & & \multirow{4}{*}{-50} & 193 & \multirow{4}{*}{$0.28 \pm 0.09$} & \multirow{4}{*}{$-76.7 \pm 26.3$} & $-52.2 \pm 12.1$ & $-2.0 \pm 6.5$ \\
\hline & $\mathrm{He}$ & 6 & $2015-10-26-$ & & 187 & & & $-55.1 \pm 9.9$ & $-3.7 \pm 6.7$ \\
\hline & $\mathrm{Ce}$ & 6 & 2016-11-04 & & 151 & & & $-54.8 \pm 11.0$ & $-4.2 \pm 5.1$ \\
\hline & $\mathrm{Pw}$ & 6 & & & 182 & & & $-51.5 \pm 10.8$ & $-4.5 \pm 6.7$ \\
\hline \multirow{2}{*}{ Krycklan } & S04 & 7 & $2015-09-22-$ & \multirow{2}{*}{-30} & 164 & $0.72 \pm 0.07$ & \multirow{2}{*}{$-102.8 \pm 32.5$} & $-88.2 \pm 5.0$ & $0.4 \pm 2.2$ \\
\hline & $\mathrm{S} 22$ & 7 & 2016-09-20 & & 149 & $0.19 \pm 0.04$ & & $-80.5 \pm 8.4$ & $0.2 \pm 2.7$ \\
\hline \multirow{2}{*}{$\begin{array}{l}\text { Wolf } \\
\text { Creek }\end{array}$} & PL & 9 & $\begin{array}{c}2015-08-25- \\
2016-09-20\end{array}$ & -85 & 49 & $0.12 \pm 0.12$ & \multirow{2}{*}{-143.8} & $-154.6 \pm 11.1$ & $-5.4 \pm 15.7$ \\
\hline & $\mathrm{RP}$ & 10 & $\begin{array}{c}2015-06-27- \\
2016-09-19\end{array}$ & -40 & 52 & $0.42 \pm 0.11$ & & $-159.8 \pm 8.8$ & $-8.3 \pm 14.1$ \\
\hline
\end{tabular}


Table 3 Results of multiple linear regression models to explain the soil water lc-excess data pooled for each sampling site over different time periods: all available data, spring, summer, and autumn (as shown in Figure 6). The significance level for each parameter is given according to ANOVA of the linear models. $* * *=p<0.001 ; * *=p<0.01 ; *=p<0.05, \stackrel{\bullet}{=}=0$. $<$. 10 , n.s. indicates parameters that were not significant for the model. Percentage in brackets show the relative importance of the explanatory parameter. Note that the lc-excess data was reciprocally transformed for "All data" and "Summer" to get normal distributions and that the lcexcess of the samples taken in autumn was not normally distributed.

\begin{tabular}{|c|c|c|c|c|}
\hline Multiple linear model & All data & Spring & Summer & Autumn \\
\hline Multiple $r^{2}$ (adjusted) & $0.88(0.87)$ & $0.74(0.70)$ & $0.87(0.84)$ & $0.98(0.97)$ \\
\hline Factors & & & Estimate & \\
\hline Intercept & $-0.75 \pm 0.238$ & $1.89 \pm 0.53$ & $-0.43 \pm 0.18$ & $9.84 \pm 0.79$ \\
\hline $\mathrm{P}_{30}$ & & & $\begin{array}{c}0.31 \pm 0.04^{* * * *} \\
(83 \%)\end{array}$ & $\begin{array}{c}-0.01 \pm 0.16^{* * * *} \\
(27 \%)\end{array}$ \\
\hline $\mathrm{P}_{7}$ & $\begin{array}{c}0.23 \\
(100 \%)\end{array}$ & $\begin{array}{c}0.80 \pm 0.15 \\
(81 \%)\end{array}$ & & \\
\hline $\mathrm{T}_{30}$ & & $\begin{array}{c}0.42 \pm 0.15 * \\
\quad(19 \%)\end{array}$ & $\begin{array}{c}0.12 \pm 0.04^{*} \\
(17 \%)\end{array}$ & $\begin{array}{c}-3.22 \pm 0.23 * * * \\
(26 \%)\end{array}$ \\
\hline VSM & n.s. & n.s. & n.s. & $\begin{array}{c}-3.36 \pm 0.26^{* *} \\
(9 \%)\end{array}$ \\
\hline$P_{30}: T_{30}$ & & n.s. & n.s. & $\begin{array}{c}-0.21 \pm 0.07 * * \\
(3 \%)\end{array}$ \\
\hline $\mathrm{T}_{30}: \mathrm{VSM}$ & n.s. & n.s. & n.s. & $\begin{array}{c}2.23 \pm 0.16^{* * * *} \\
(35 \%)\end{array}$ \\
\hline
\end{tabular}




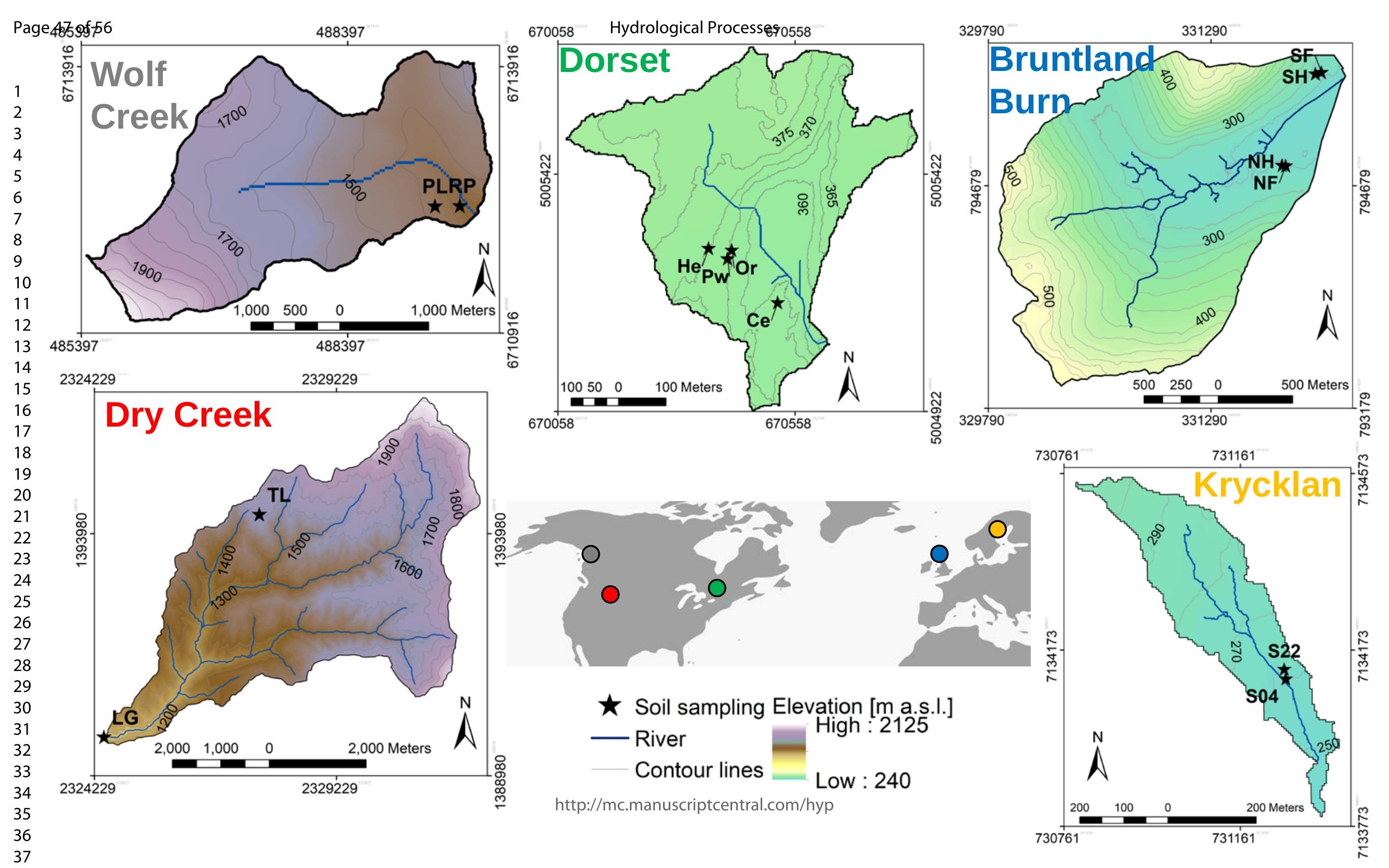


Precipitationdrological Processes

Soil water Page 48 of 56

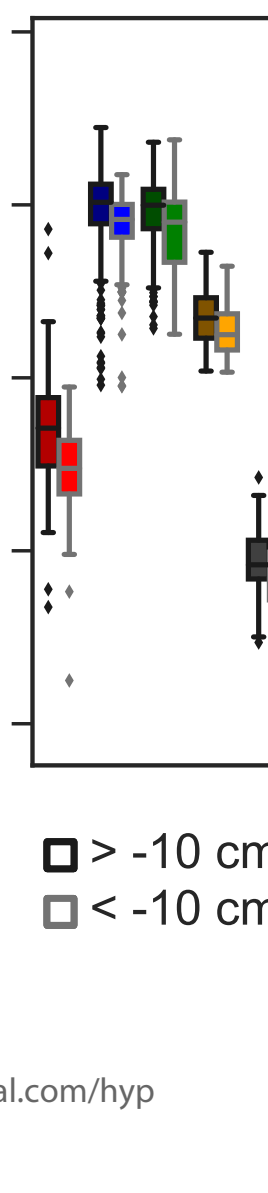

$\Delta>-10 \mathrm{~cm}$

$0<-10 \mathrm{~cm}$

- Bruntland Burn

- Dorset

- Krycklan

- Wolf Creek

$-100$

$-150$

$-200$

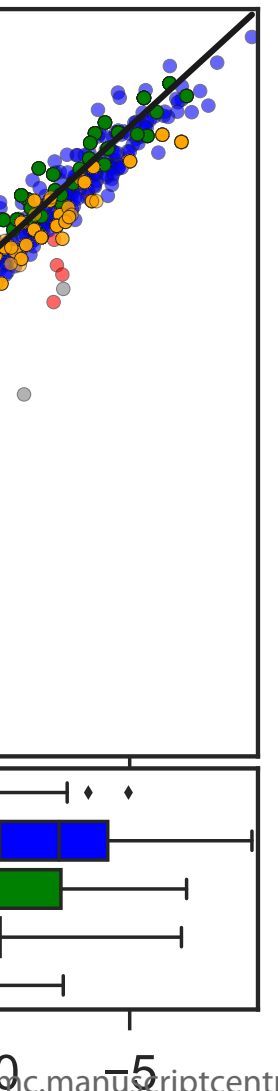

-15 http:M/Ac.mant5riptcentral.com/hyp

$\delta^{18} \mathrm{O}[\% o]$
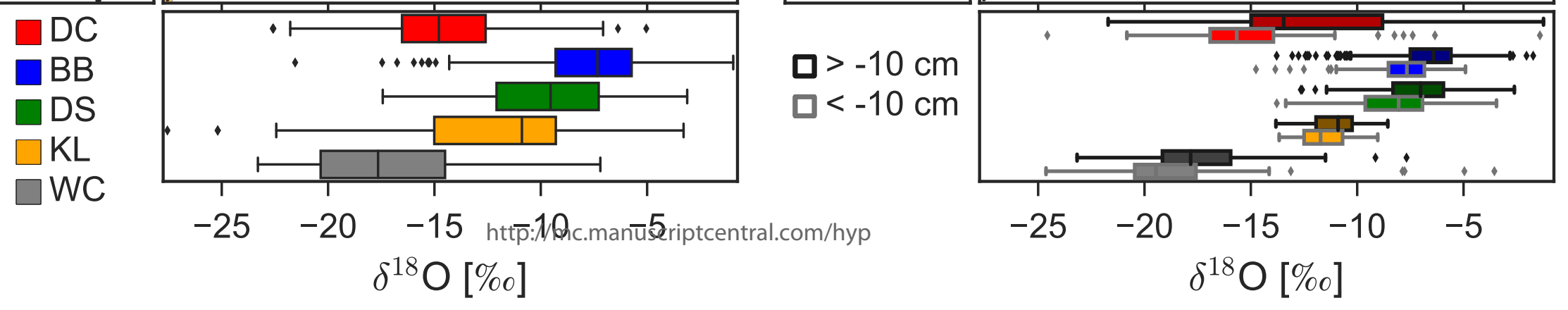


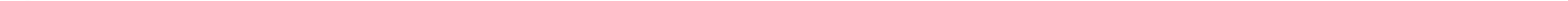




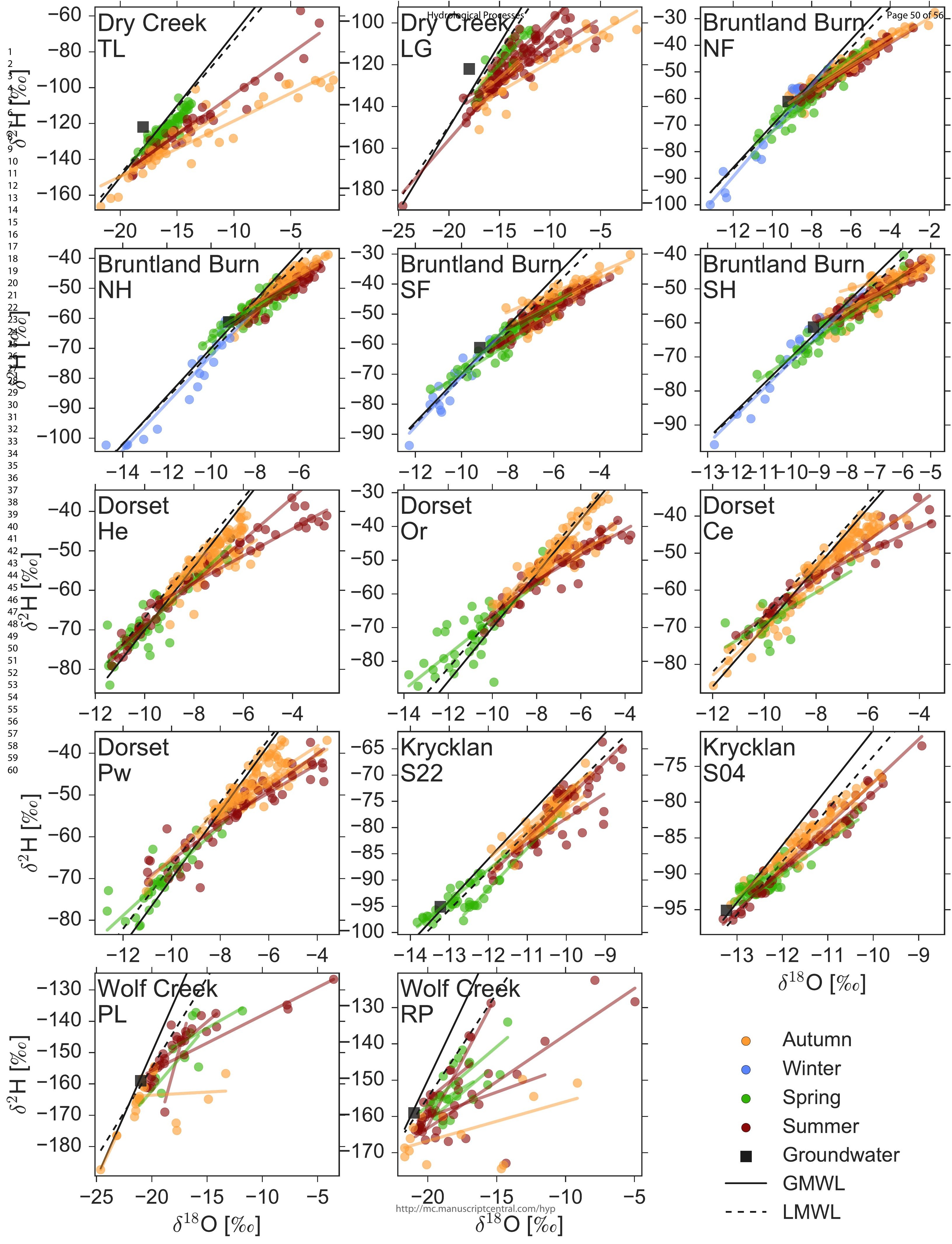




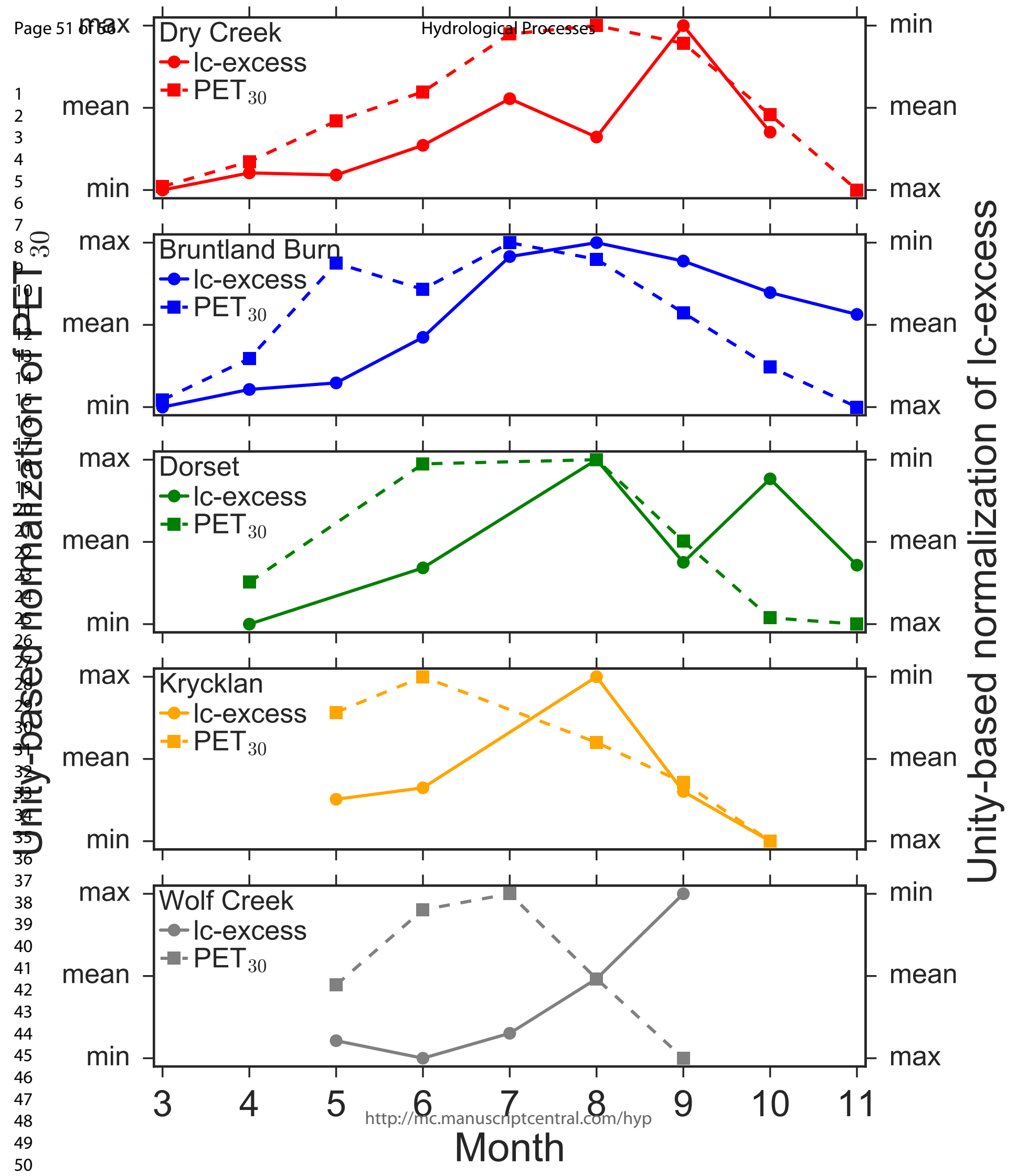




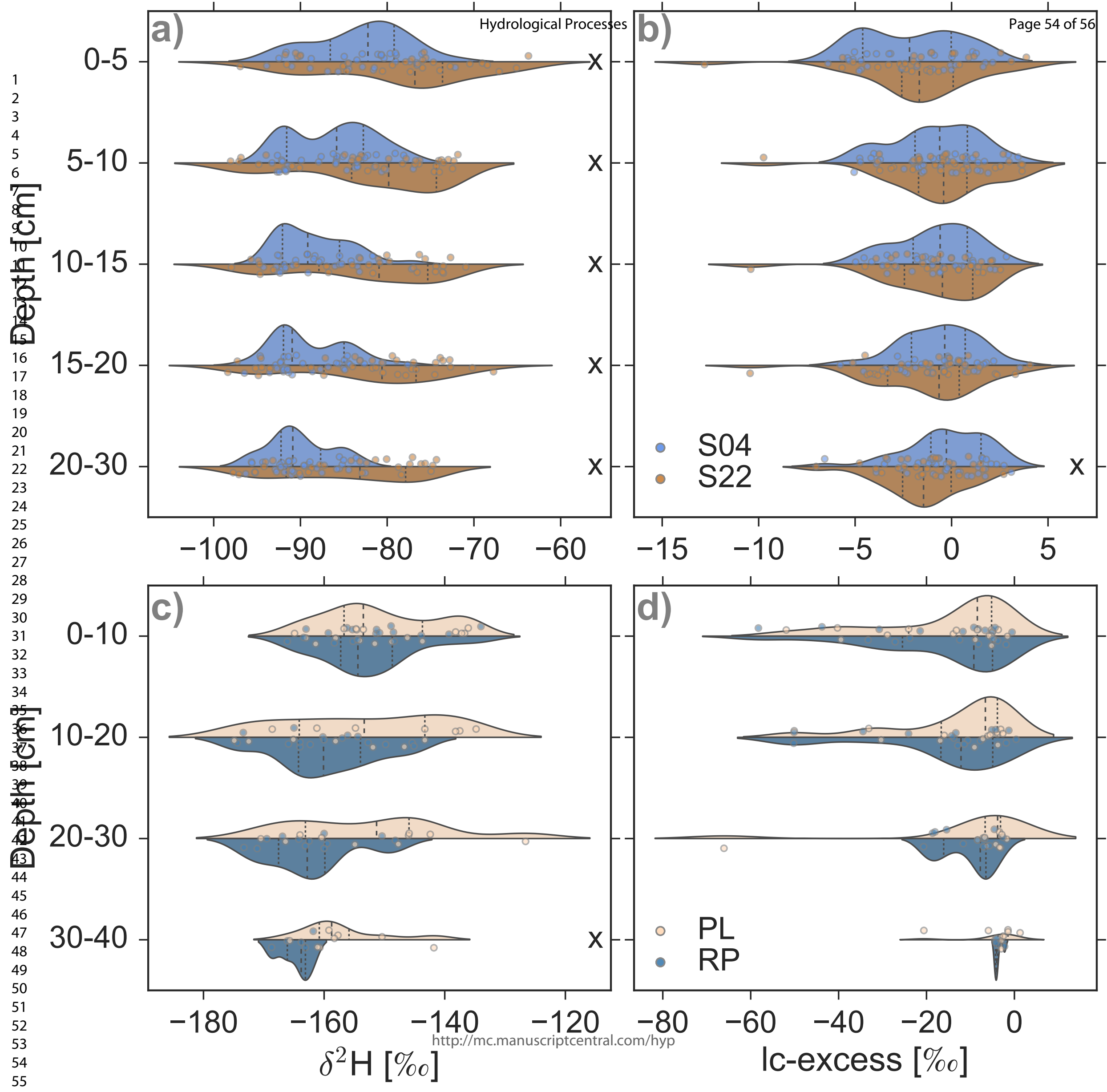




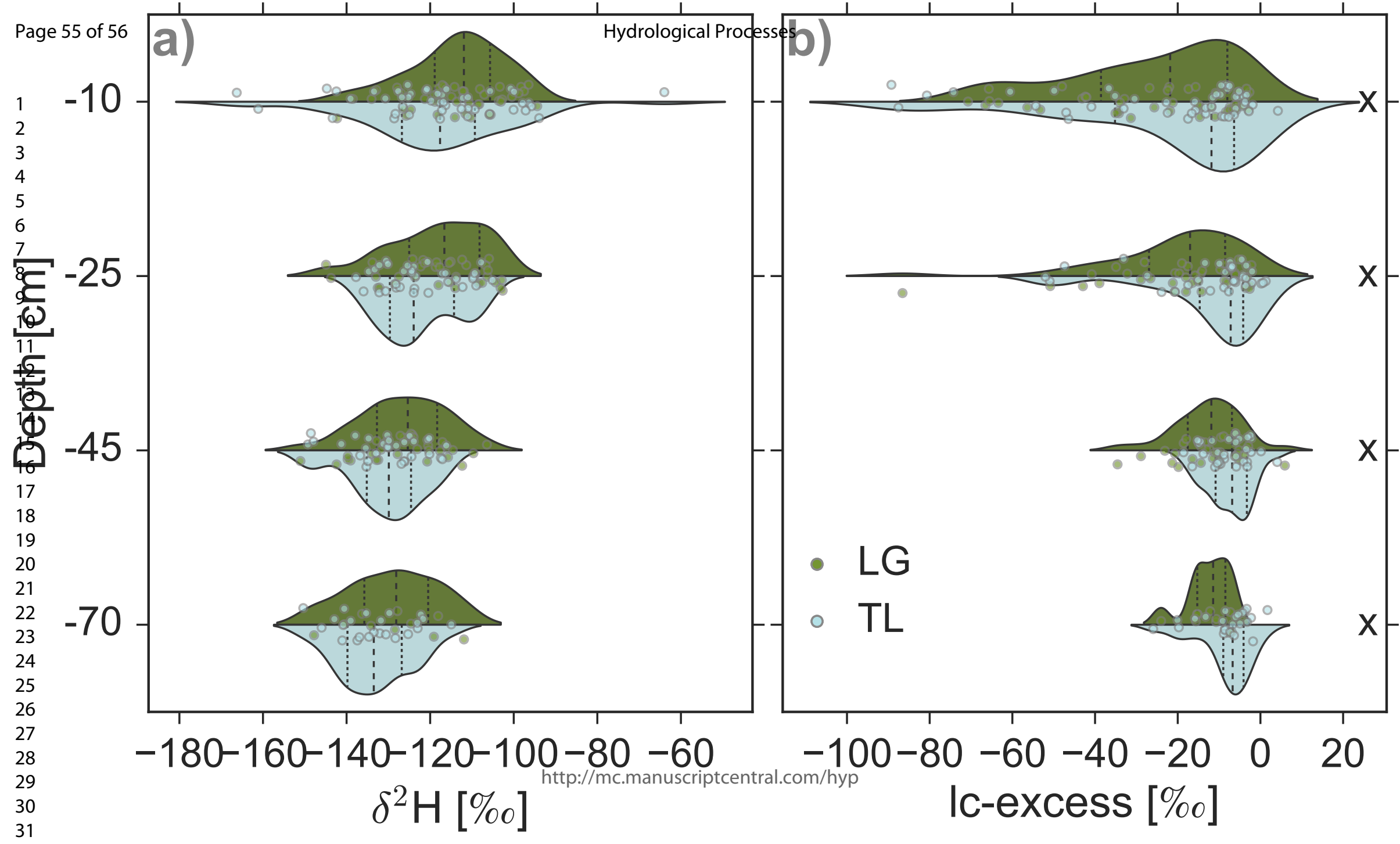




\begin{tabular}{|c|c|c|c|c|c|c|c|}
\hline Soil & \multicolumn{4}{|c|}{$r$} & $\mathrm{~m}$ & \multirow{2}{*}{\multicolumn{2}{|c|}{ Site }} \\
\hline depth & $P_{2}$ & $P_{7}$ & $P_{14}$ & $P_{30}$ & $P_{30}$ & & \\
\hline-10 & 0.54 & 0.69 & 0.30 & 0.00 & 0.00 & & \\
\hline-25 & -0.05 & 0.00 & -0.29 & -0.74 & -0.15 & $\rightleftarrows$ & 产 \\
\hline-45 & -0.05 & 0.06 & -0.33 & -0.77 & -0.15 & & \\
\hline-10 & -0.23 & -0.23 & -0.16 & -0.37 & -0.07 & & 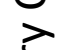 \\
\hline-25 & -0.23 & -0.23 & -0.17 & -0.37 & -0.07 & ت & \\
\hline-45 & 0.09 & 0.09 & 0.01 & 0.09 & 0.04 & & \\
\hline-2.5 & 0.23 & 0.59 & 0.89 & 0.77 & 1.00 & & \\
\hline-7.5 & 0.18 & 0.41 & 0.78 & 0.87 & 0.66 & & \\
\hline-12.5 & 0.18 & 0.30 & 0.68 & 0.86 & 0.61 & & \\
\hline-17.5 & 0.13 & 0.19 & 0.47 & 0.79 & 0.53 & & \\
\hline-2.5 & 0.25 & 0.58 & 0.89 & 0.71 & 0.92 & & \\
\hline-7.5 & 0.21 & 0.43 & 0.78 & 0.64 & 0.60 & I & 든 \\
\hline-12.5 & 0.25 & 0.37 & 0.73 & 0.67 & 0.50 & & गे \\
\hline-17.5 & 0.30 & 0.39 & 0.72 & 0.78 & 0.64 & & ర્ટ \\
\hline-2.5 & 0.28 & 0.62 & 0.91 & 0.78 & 0.99 & & \\
\hline-7.5 & 0.24 & 0.52 & 0.80 & 0.87 & 0.73 & & 立 \\
\hline-12.5 & 0.39 & 0.48 & 0.69 & 0.87 & 0.66 & & \\
\hline-17.5 & 0.46 & 0.46 & 0.74 & 0.92 & 0.69 & & \\
\hline-2.5 & 0.16 & 0.56 & 0.89 & 0.74 & 0.87 & & \\
\hline-7.5 & 0.09 & 0.37 & 0.76 & 0.85 & 0.63 & & \\
\hline-12.5 & 0.05 & 0.11 & 0.42 & 0.76 & 0.48 & & \\
\hline-17.5 & 0.14 & 0.20 & 0.47 & 0.78 & 0.50 & & \\
\hline-2.5 & 0.88 & 0.80 & 0.38 & 0.97 & 0.64 & & \\
\hline-7.5 & 0.67 & 0.77 & 0.35 & 0.96 & 0.59 & & \\
\hline-12.5 & 0.75 & 0.80 & 0.15 & 0.92 & 0.59 & & \\
\hline-17.5 & 0.48 & 0.72 & 0.01 & 0.83 & 0.56 & & \\
\hline-25.0 & 0.63 & 0.86 & 0.16 & 0.81 & 0.46 & & 兰 \\
\hline-2.5 & 0.78 & 0.96 & 0.43 & 0.92 & 0.32 & & \\
\hline-7.5 & 0.16 & 0.67 & 0.13 & 0.49 & 0.17 & & \\
\hline-12.5 & 0.27 & 0.70 & 0.02 & 0.34 & 0.10 & & \\
\hline-17.5 & -0.02 & 0.45 & -0.09 & 0.22 & 0.07 & & \\
\hline-25.0 & -0.22 & 0.29 & -0.18 & -0.01 & 0.00 & & \\
\hline
\end{tabular}

\begin{tabular}{|c|c|c|c|c|c|c|c|}
\hline \multirow{2}{*}{$\begin{array}{c}\text { Soil } \\
\text { depth }\end{array}$} & \multicolumn{4}{|c|}{$r$} & \multirow{3}{*}{$\begin{array}{c}\mathrm{m} \\
\mathrm{P}_{30} \\
\mathbf{0 . 3 6}\end{array}$} & \multirow{2}{*}{\multicolumn{2}{|c|}{ Site }} \\
\hline & $\mathrm{P}_{2}$ & $\mathrm{P}_{7}$ & \multirow{2}{*}{$\frac{P_{14}}{0.77}$} & \multirow{2}{*}{$\frac{P_{30}}{0.82}$} & & & \\
\hline-2.5 & 0.67 & 0.80 & & & & \multirow{7}{*}{$\stackrel{0}{1}$} & \multirow{28}{*}{ 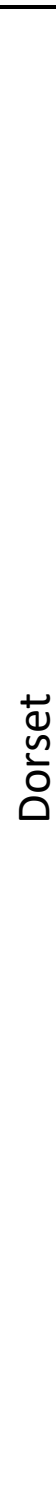 } \\
\hline-7.5 & 0.31 & 0.26 & 0.25 & 0.64 & 0.23 & & \\
\hline-12.5 & 0.07 & 0.27 & 0.33 & 0.49 & 0.19 & & \\
\hline-17.5 & -0.24 & -0.21 & -0.13 & 0.22 & 0.12 & & \\
\hline-22.5 & -0.29 & -0.31 & -0.24 & 0.16 & 0.08 & & \\
\hline-27.5 & -0.15 & -0.20 & -0.13 & 0.31 & 0.16 & & \\
\hline-32.5 & -0.17 & -0.30 & -0.24 & 0.27 & 0.14 & & \\
\hline-2.5 & 0.41 & 0.80 & 0.77 & 0.46 & 0.26 & \multirow{7}{*}{ ò } & \\
\hline-7.5 & 0.27 & 0.39 & 0.64 & 0.67 & 0.47 & & \\
\hline-12.5 & 0.26 & 0.26 & 0.54 & 0.72 & 0.65 & & \\
\hline-17.5 & -0.01 & 0.17 & 0.54 & 0.65 & 0.56 & & \\
\hline-22.5 & 0.03 & -0.05 & 0.30 & 0.57 & 0.50 & & \\
\hline-27.5 & -0.04 & -0.14 & 0.23 & 0.49 & 0.43 & & \\
\hline-32.5 & -0.15 & -0.22 & 0.11 & 0.34 & 0.35 & & \\
\hline-2.5 & 0.85 & 0.96 & 0.89 & 0.89 & 0.67 & \multirow{7}{*}{$\stackrel{0}{\cup}$} & \\
\hline-7.5 & 0.70 & 0.79 & 0.74 & 0.90 & 0.47 & & \\
\hline-12.5 & 0.32 & 0.41 & 0.41 & 0.69 & 0.39 & & \\
\hline-17.5 & 0.28 & 0.32 & 0.34 & 0.70 & 0.40 & & \\
\hline-22.5 & 0.24 & 0.17 & 0.22 & 0.68 & 0.34 & & \\
\hline-27.5 & 0.13 & 0.06 & 0.11 & 0.57 & 0.35 & & \\
\hline-32.5 & -0.04 & 0.00 & -0.06 & 0.30 & 0.17 & & \\
\hline-2.5 & 0.02 & 0.65 & 0.83 & 0.68 & 0.34 & \multirow{7}{*}{3} & \\
\hline-7.5 & -0.16 & 0.21 & 0.57 & 0.69 & 0.38 & & \\
\hline-12.5 & -0.22 & -0.01 & 0.43 & 0.57 & 0.38 & & \\
\hline-17.5 & -0.35 & -0.06 & 0.39 & 0.47 & 0.32 & & \\
\hline-22.5 & -0.27 & 0.02 & 0.41 & 0.58 & 0.44 & & \\
\hline-27.5 & -0.19 & -0.11 & 0.28 & 0.58 & 0.44 & & \\
\hline-32.5 & -0.32 & -0.25 & 0.40 & 0.44 & 0.36 & & \\
\hline-5 & 0.41 & 0.39 & 0.52 & 0.71 & 0.28 & \multirow{4}{*}{$\vec{a}$} & \multirow{6}{*}{ 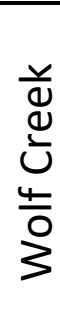 } \\
\hline-15 & 0.00 & 0.06 & 0.56 & 0.59 & 0.43 & & \\
\hline-25 & 0.63 & 0.72 & 0.74 & 0.70 & 0.40 & & \\
\hline-35 & 0.07 & 0.26 & 0.34 & 0.06 & 0.02 & & \\
\hline-5 & -0.43 & 0.01 & -0.19 & 0.15 & 0.03 & \multirow{2}{*}{$\frac{a}{\alpha}$} & \\
\hline-15 & 0.12 & 0.04 & 0.16 & -0.01 & -0.01 & & \\
\hline
\end{tabular}

Color

bar: \begin{tabular}{r|r|r|r|}
-1.00 & 0.00 & 0.50 & 1.00 \\
\hline
\end{tabular} 